\title{
SUCCESSION OF MAMMALIAN FAUNAS ON TRINIDAD, WEST INDIES
}

By

ELIZABETH SCHWARZ WING

\begin{abstract}
A DISSERTATION PRESENTED TO THE GRADUATE COUNCIL OF THE UNIVERSITY OF FLORIDA

IN PARTLAL FULFILLMENT OF THF REQUIREMENTS FOR THE DEGREE OF DOCTOR OF PHILOSOPHY
\end{abstract}

UNIVERSITY OF FLORIDA

February, 1962 


\section{ACKNOWLEDGMENTS}

This study could not have been done without the cooperation of many persons and organizations to whom I am deeply indebted. I should like to thank my graduate supervisory commlttee, Drs. Archie F. Carr, James R. Redmond, and John M. Goggin, Mr. Clayton E. Ray, and particularly my chairman, Dr. James N. Layne, for their advice and encouragement throughout this study. I am also most grateful for the loan of specimens from Miss Barbara Lawrence of the Museum of Comparative Zoology, Dr. Richard Van Gelder of the American Museum of Natural History, Drs. H. G. Kugler and S. Schaub of the Basel Natural History Museum, and Mr. J. A. Bullbrook of the Royal Victoria Institute. Field work during the summer of 1959 was carried out with the assistance of a National Science Foundation Summer Fellowship for Graduate Teaching Assistants and with the help and hospitality of Texaco Trinidad, Inc., and Trinidad Petroleum Development. I would also like to extend my thanks to Dr. H. G. Kugler, Dr. K. Barr, Mr. J. A. Bullbrook, Dr. C. C. Wilson, and Dr. I. Rouse for help in connection with various phases of the study. Finally, I wish to express my gratitude to my parents and husband for their help and constant encouragement. 
TABLE OF CONTENTS

ACKNOWLEDGMENTS. . . . . . . . . . . . . . 11

LIST OF TABLES .......................... iv

LIST OF ILLUSTRATIONS. . . . . . . . . . . . . v v

INTRODUCTION . . . . . . . . . . . . . . . . 1

MATERIALS AND METHODS. . . . . . . . . . . . . 3

POST-PLEISTOCENE HISTORY OF THE GEOLOGIC, CLIMATIC, AND

VBGETATIONAL FEATURES OF TRINIDAD. ........... 7

Geology ................... . . . . 7

Climate . . . . . . . . . . . . . . . 8

Vegetat1on.............................. 17

THE PRE-HUMAN MAMALIAN FAUNA OF TRINIDAD . . . . . . 25

Foss1l Mammals of Trin1dad. . . . . . . . . . . 25

Zoogeographic S1gnificance of Pre-human Fauna...... 32

MAMMALIAN FAUNA AS REPRESEIVTED IN INDIAN MIDDENS . . . . . 33

Description of Sites. . . . . . . . . . 33

Intersite Comparisons ............ 47

HISTORIC MAMMALIAN FAUNA . . . . . . . . . . . 53

List of Terrestr1al Mamals . . . . . . . . . . 54

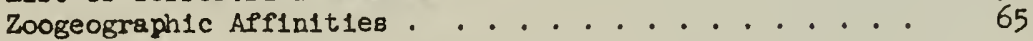

DISCUSSION ............................... 67

SUMMARY AND CONCLUSIONS .................... 68

LITERATURE CITED . . . . . . . . . . . . . . . . 73

BIOGRAPHICAI SKETCH. . . . . . . . . . . 76 


\section{LIST OF TABLES}

Table

Page

1 Rainfall data for selected stations on Trinidad . . . . If

2 Measurements of the alveolar cheek tooth row of various species of Zygodontomys . . . . . . . . . 29

3 Meesurements of fossil Zygodontomys . . . . . . . . 30

4 Correlation of periods of occupation on Trinidad and ceramic styles............... . 34

5 Relative abundance of mammals at different time perlods withln the St. John site. . . . . . . . 36

6 Relative abundance of mamals recorded from nine

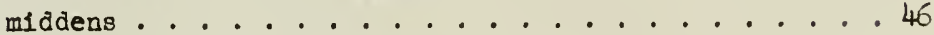

7 Measurements of S1gmodon cf. hirsutus. . . . . . . 62 


\section{IIST OF ILUUSTRATIONS}

F1gure

Page

1 Shoreline of Trinidad, approximately 17,820

years ago... . . . . . . . . . . . . . . 9

2 Shoreline of Trinldad, approximately 8,000

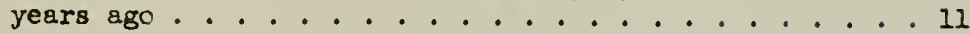

3 Physlographic reglons of Trinldad . . . . . . . . 13

4 Plelstocene vegetation of Venezuela and Trinidad . . . 19

5 Pre-Columbian vegetation of Trin1dad. . . . . . . . . 21 


\section{INTRODUCTION}

Animal remains excavated from Indian middens constitute a source of valuable information to both the archeologist and the zoologist (Taylor, 1957). These materials are particularly significant, since they often can be accurately dated, in that they may provide information about the transition between Plelstocene and Recent time, a period In which world biotas underwent rapld changes (Burt, 1961). From the animals represented in a midden, much about the faunal composition of an area at a given time may be revealed. Changes in the range of certain forms may also be indicated. Such changes may in turn throw light on the nature of past ecological conditions in a given region. Midden remains occasionally include species that are new to science. More often, comparison of specimens from middens with those of the same species now inhabiting the region shows certain differences, analysis of which may lead to a better understanding of evolutionary processes. From an archeological standpoint, the study of animal remains from middens contributes to a more nearly complete understanding of the environmental milieu of the particular society under consideration. In addition it provides data on which to base cultural hypotheses as to the nature of hunting and butchering techniques, food taboos, and the non-alimentary uses of animals. By integrating data on fossil and recent faunas of the region a greater perspective on this type of assemblage is gained and thereby a better understanding of 1 . 
Because of its dynamic geological history and attendant climatic and vegetational changes, Trinidad, West Indies, is of considerable zooarcheological interest. It has become separated from the mainland of South America, from which its fauna and aborlginal population were derived since it became inhabited by man.

The present study is an attempt to apply the zooarcheological approach in an analysis of the mammalian remains from aboriginal sites In Trin1dad. These sites encompass a time-span from approximately 2750 years ago to historic times. In addition, an effort has been made to 1ntegrate this faunal assemblage with data on both pre-human and historlc mammals in order to gain some knowledge of the history of the mammalian fauna of Trinidad from the Plelstocene to the present day as related to geolog1c, ecolog1c, and human factors. 
MATERIALS AND METHODS

The materials upon which this study is based come from $a$ number of sources. Many of the fossil finds on Trinidad have been made by Dr. H. G. Kugler in the course of his career as oil geologist for Texaco Trinidad, Inc. In 1922, he discovered a vertebrate-fossilbearing stratum of 011 sands while making a test pit at Apex (Trinidad) 011fields, Inc. near Fyzabad. The fossils that were collected are in the Basel Natural History Museum collect1ons. A similar deposit nearby at the Forest Reserve of Texaco Trinldad, Inc. wes found in 1957 when the site was belng cleared for o1l well Number 1060. An almost complete skeleton of Glyptodon was excevated, and shipped along with some fragments to the American Museum of Natural H1story. None of th1s material has yet been prepared or catalogued. A carbon-14 date based upon wood associated with Megatherium bones was also taken at this site.

My husband and I conducted fleld work in Trinidad during the summer of 1959 with the objectives of collecting more foss1l, midden, and Recent vertebrate material and of getting first hand knowledge of the ecology of the island. All specimens collected by us are deposited In the appropriate University of Florlda Collection. An attempt to relocate the fossil locality at Apex was unsuccessful in spite of help from the Apex Company. At the site at Forest Reserve, several bones of larger mammals were collected, and a stratum containing small vertebrate fossils was discovered. The small fosg1ls were extracted from the ofl sands in whlch they were embedded by soaking large clumps of it 
for several days in gasoline, then bolling the clumps to break them up, and finally washing the residue through screens. Initially 20 , 140 , and 230 gauge screens were used but since very few fossils went through the 20 gauge screen, subsequent batches were washed only through a 50 gauge screen.

The bulk of the midden materials was excavated by Dr. I. Rouse, Yale University, and Dr. J. M. Goggin, University of Florida, in 1946 and 1953, under the auspices of the Yale Cartbbean Research Program and Graduate School of the University of Florida. Seven sites--St. Joseph, Mayo, St. John, Cedros, Erin, Palo Seco, and Quinam--were represented in these collections. The excavations were mede by removing one or more sections two meters square. Each section was divided vertically into a number of levels $20 \mathrm{~cm}$. In depth. The bones as well as the artifacts from each level were kept separate, so that stratigraphic changes could subsequently be analyzed. Another collection of midden bones which was avallable for study was made by Dr. Kugler at Cedros. Th1s was not an excavation, but rather a surface collection. Additional material came from an excavation made at the Erin site by Mr. J. A. Bullbrook, of the Royal Victoria Institute. Although this site had been excavated in a manner similar to that employed by Rouse and Goggin, the bones were not kept segregated into their strat1graphic sequence.

In the sumer of 1959, I visited six known archeological sites in Trinidad for the purposes of making ecological observations at each site and to collect additional surficial material. The sites 
studied Included Chagonaray, Palo Seco, Mayaro, Guayaguayare, Mayo, and St. John.

The zooarcheological material obtained from Trinldad middens was in quite good condition compared to similar material from other areas. Only about 50 percent of the material was too fragmentary to permit identification. Of the identifiable component, about 50 percent was mammal bones, and the remainder was $\mathrm{fish}$, rept1le, and bird. The mammal elements identified totaled 4884 . In this study the "minimum number of individuals" is used as an index of the relative abundance of a particular species in a sample of midden remains. For each species this is determined by the count of the most numerous skeletal element in a given lot. In some cases this number may validly be 1ncreased by the addition of specimens of an age group not represented in a series of the most frequent element. For example, if the most abundant element of a given species in $a$ level was the mandibular ramus and there were three right adult rami and one left juvenile ramus, the minimum number of individuals would be four. Data on the modern fauna are derived largely from the literature and from my notes on Trinldad mammals. In the course of my own field work in Trinidad, Recent mammals were collected and their ecology studied, with emphasis on those forms which are of 1mportance in middens. Smaller species were collected in traps. Since the large game animals are very scarce, I accompanied professional hunters, and acquired the unused parts of their catches. I also obtained many bones, particularly gkulls and feet of wild mammals, in modern kitchen middens 
around the hunters' houses. Further data on Recent mammals were obtalned through the analysis of owl pellets collected by the late F. W. Urich of St. Augustine and lent to me by Dr. H. G. Kugler and Dr. S. Schaub from the Basel Natural History Museum.

Where adequate series were available, comparisons of skeletal measurements of midden and Recent mammals of the same species were undertaken with the aim of detecting differences in size that might perhapg be correlated with ecological or other factors. 
POST-PLEISTOCENE HISTORY OF THE GEOLOGIC, CLDMATIC, AND VEGETATIONAL FEATURES OF TRINIDAD

For the understanding of the history of the mamallan fauna of Trinidad, a knowledge of the post-Pleistocene geological events, and the climatic and vegetational changes attendant upon them, is of primary importance. A brief sketch of these changes will, perhaps, ald in placing the history of the fauno of the island in its proper context.

\section{Geology}

Although Trinidad is commonly thought of as one of the Antilles, and is politically a member of the West Indian Federation, it is geologically and biologically closely associated with the South Amerlcan mainland. The island is composed of sediments probably derived princlpally from the Gulana shield which extends roughly as far south as the present frontier of Brazil and Includes Trinidad, and possibly Tobago, at the northern limits of its influence. According to Dr. Kugler (personal communication) several Plelstocene marine terraces are traceable, and he has recognized at least seven of these, ranging in elevation from five to 330 feet, which can be correlated closely with similar marine terraces in Venezuela. After the last glaciation, there was one continuous land mass encompassing what is now Trintad, the Gulf of Par1a, the Serpent's Mouth, and Venezuela. Thereafter a general trend of rising sea level is observable. Koldew1gn (1958) states that the shoreline at an estimated 17,820 years ago was at the present 24-fathom line (Figure 1). By about 8,000 
years ago (Figure 2), the shoreline had risen to the present 12-fathom mark (Nota, 1958). Roughly 700 years ago, the drainage of the Manamo Branch of the Orinoco River Into the Gulf of Paria increased in volume, thereby further enlarging the Gulf, and completing the separation of Trinided as an island from the mainland (Koldewign, 1958). At the present time, the Islond is subsiding, as is evidenced by the coastal erosion Indicated by the landslips onto the beaches. Many instances can be seen of roads that have been completely undermined by wave action and of coconut palms lying uprooted on the beach. The Chagonaray site on the south coast is being washed into the sea.

Trinldad may be divided into flve physlographic regions (Beard, 1946). The first of these comprises the mountalns of the North Range (Figure 3). Although there are three ranges in Trintdad only the North Range, which 18 an extension of the coastal cordillera of Venezuela, may be considered to be actually mountainous, with elevat1ons over 3,000 feet. The Central and South ranges constitute the second region. The elevation of these hills scarcely exceeds 1,000 feet. Just south of the North Range lies the third region, one of dissected alluvial terraces, formed of material from the mountains. The fourth and most extensive region is the dissected peneplain. This division includes all of the rest of the land except for a few coastal swamps which comprise the fifth and final reglon.

\section{Climate}

As a result of its insular nature and varied physlographic features, Trinidad has a somewhat varled climate. The most notable 
Figure 1: The shoreline of Trinidad about 17,820 years ago. The solid line is the present 24 -fathom mark which corresponds to the former shoreline, and the dotted line denotes the present geographic features of the area. 


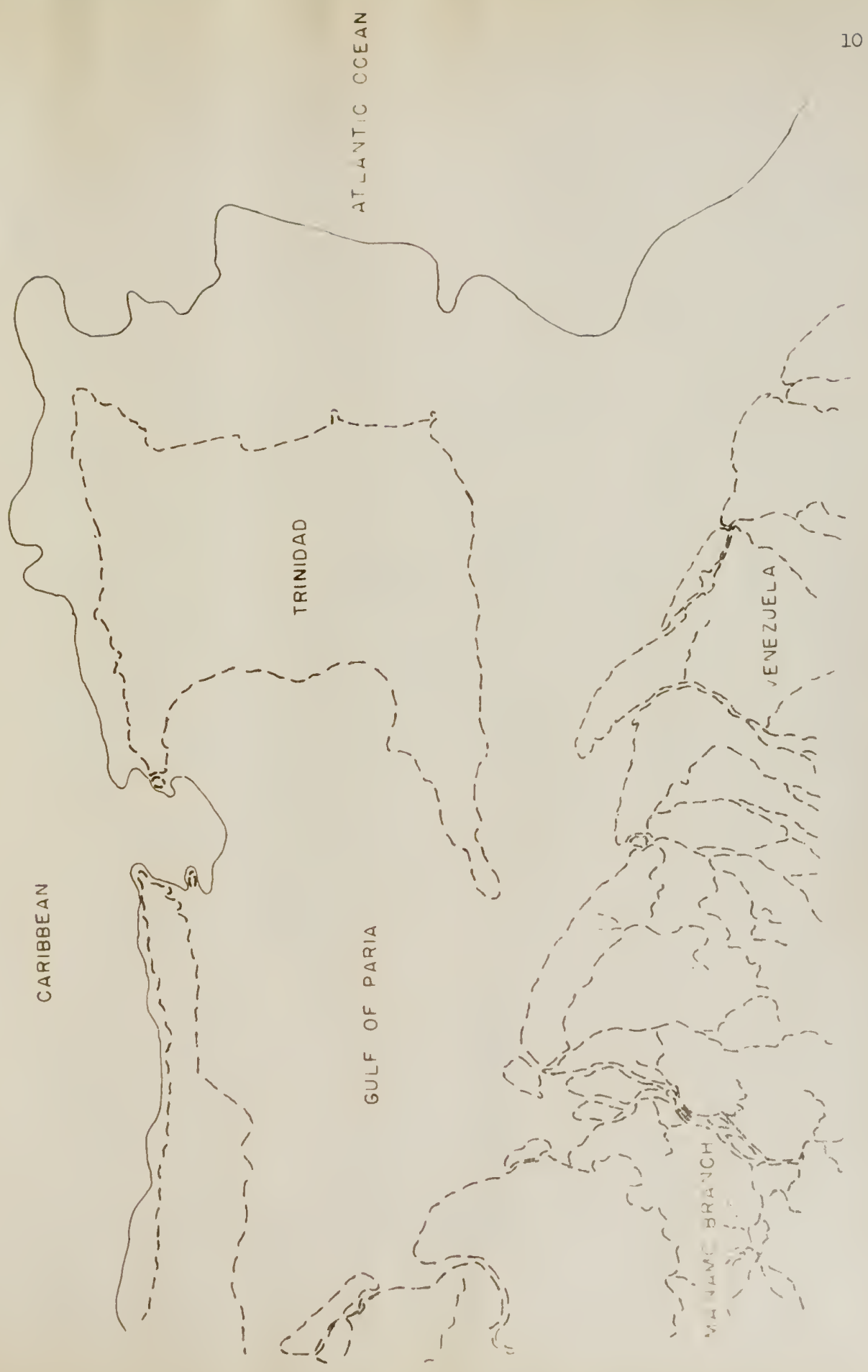


F1gure 2: The shoreline of Trinidad about 8,000 years ago.

The solid line is the present 12 -fathom mark

which corresponds to the former shoreline, and the

dotted line denotes the present geographic features of the area. 


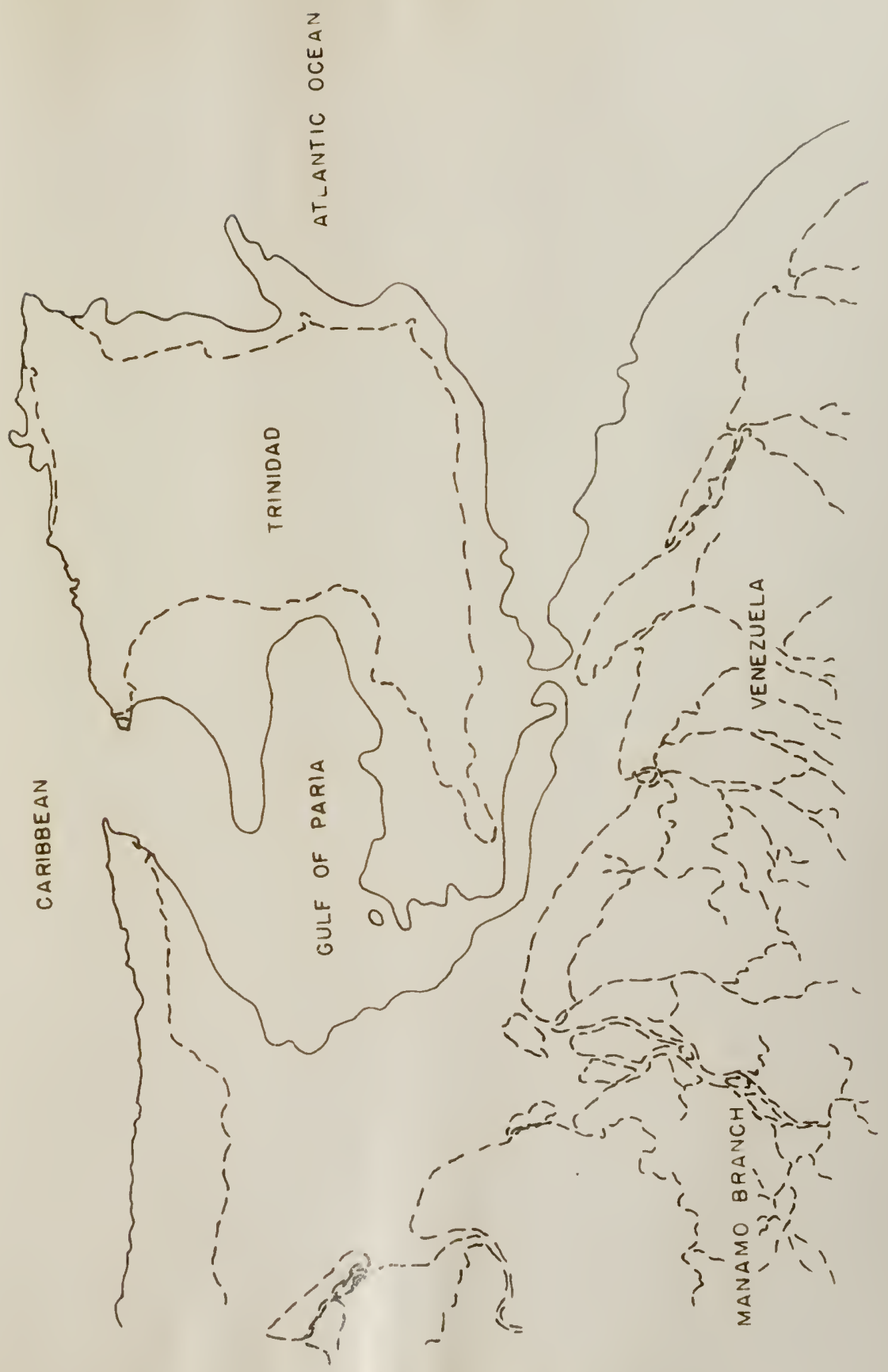


Figure 3: The physlographic regions of Trinidad. (after Beard) 


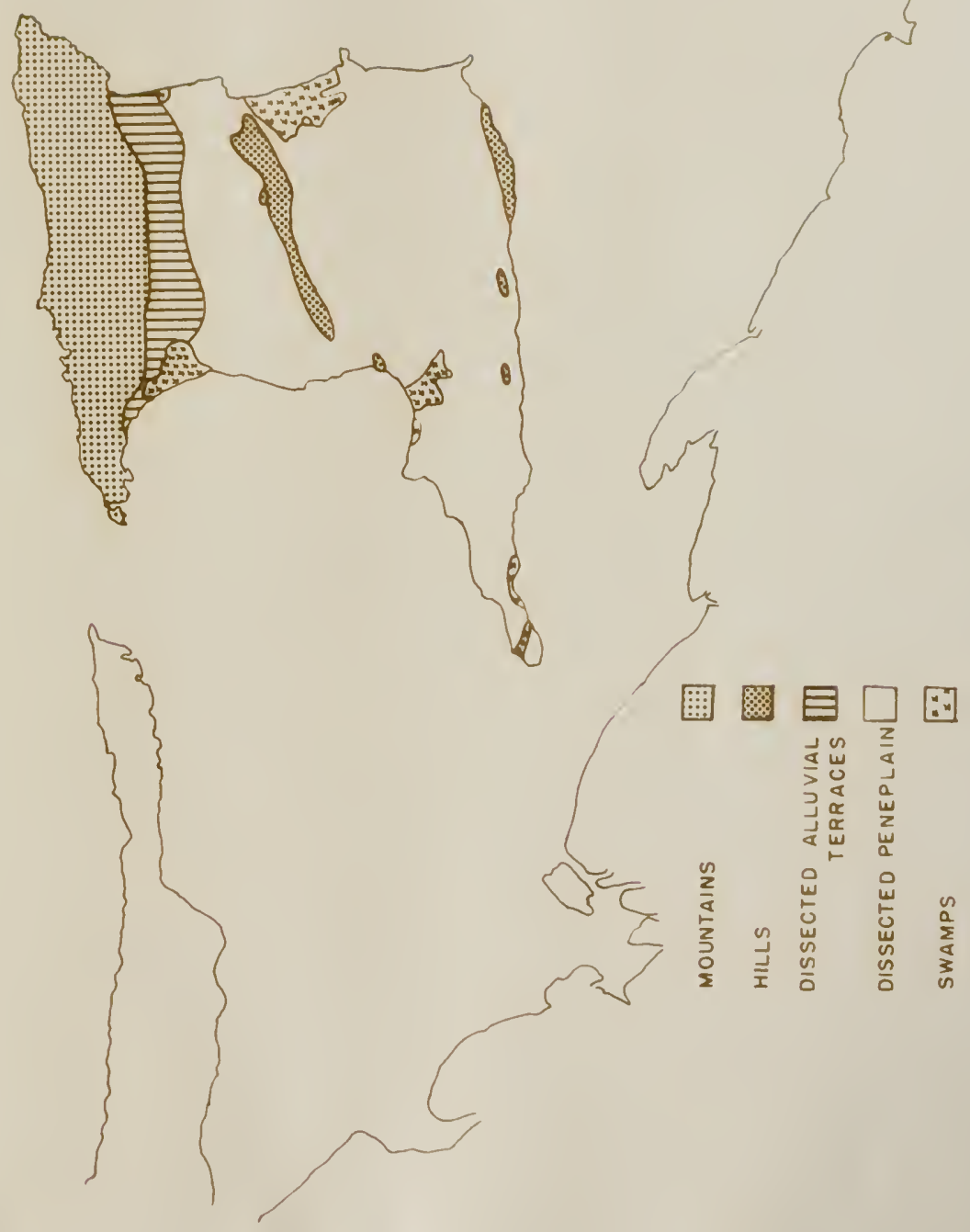


climatic zone is the montane region of the North Range, which is characterized by heavy rainfall of at least 200 inches per year and an almost continual cloud cover. The remainder of the 1sland exper1ences a seasonal climate, with two dry seasons from January through Apr1I and September through October, and two rainy seasons, as the result of shifts in the tradewinds from northeast to southeast. The windward coastal strip is affected by the wind and salt spray, and is therefore somewhat drler than the rest of the 1sland. Rainfall data for selected stations, provided by the West Indies Meteorological Service, are presented in Table 1.

Ev1dence 1ndicates that temperatures in the area of Trinldad underwent an increase, beginning about 16,500 years ago, reaching a maximum at 6,000 years ago, and thereafter declining slightly (En111an1, 1955). The enlargement of the Gulf of Paria may have had a molstening influence on Trinldad. Present day temperatures vary in the different parts of the 1sland, but on the whole are generally equable. The temperature ranges at Port-of-Spa1n, representative of the seasonal climate, vary from the average monthly maximum of $86.4^{\circ}$ F. In January to $89.8^{\circ} \mathrm{F}$. In May, and from the average monthly minimum of $67.6^{\circ}$ F. in February to $71.8^{\circ}$ F. in September. Daily temperature fluctuation is almost constant, ranging from a maximum of $18.9^{\circ}$ F. In February to a minimum of $16^{\circ} \mathrm{F}$. In September. Humldity always exceeds 50 percent and often approaches 100 percent at night (Beard, 1946). 


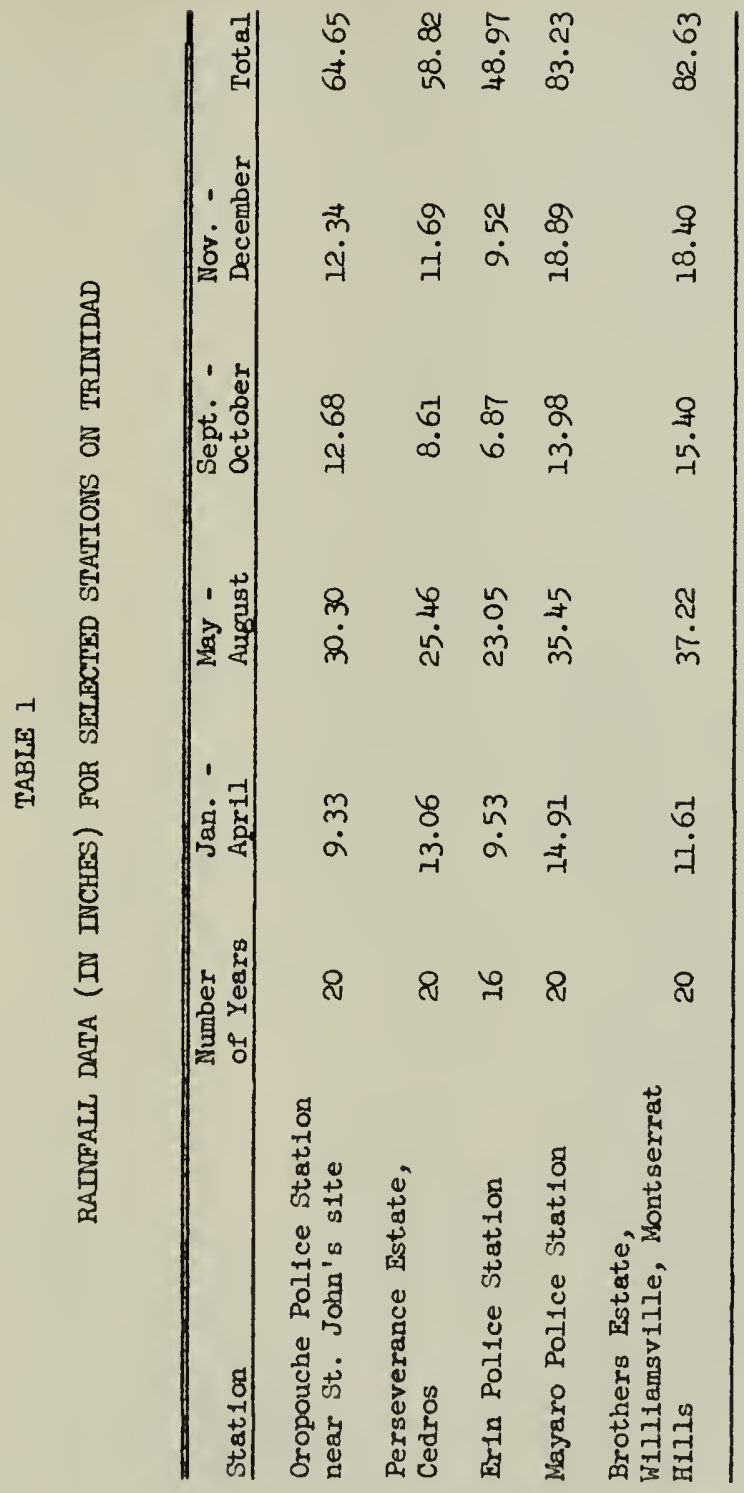




\section{Vegetat1on}

Striking changes in the vegetation of Trinfdad have accompanfed the geologic and climatic events that have influenced the 1sland. The following discussion of the vegetation 18 based upon Beard's monograph (1946) The Natural Vegetation of Trinidad. At the t1me when there was a continuous land mass Including Trinidad and the malnland, there was also an extension of the vegetation types of Venezuela into Trinidad (F1gure 4). The North Range was forested, as were some of the higher parts of the Central and South ranges, while the remalnder of what is now Trinidad and the Gulf of Parla were occupied by savannah. The savannah was dissected by streams bordered by gallery forest. The savannah formation which is now widespread In Venezuela as the "llanos," reaches to within 50 miles of the Gulf of Paria and persists as relics in a few small areas on Trinldad 1tself. The distribution of savannahs on Trinldad 1s controlled by edaphic factors. They occur in flat areas where the soll is poorly draned and the subsoll is impermeable. The solls became rejuvenated, accompanying geological changes in the area, and this resulted in the spread of forests from the streams and hills, eventually to cover nearly the entire 1sland.

Particular climatic and edaphic factors influenced the development of several vegetational types. Beard (1946) recognizes six major plant formations (F1gure 5): seasonel forest; dry evergreen forest; montane forest; intermediate forest; swamp; and marsh. Four of these are further divisible into assoclations. The seasonal formation 
Includes evergreen, semi-evergreen, and deciduous forest depending upon the avallability of molsture.

The evergreen seasonal forest requires 70 inches or more of avallable molsture, and is characterlzed by a discontinuous emergent stratum more than 100 feet in he1ght, and " . . an almost continuous canopy layer at 40-90 feet, and almost continuous lower story at 10-30 feet" (Beard, 1946, p. 38). Lianas and epiphytes are common. Consplcuous species of trees are Spondias mambin (hogplum), Carapa guianens1s (crappo), Eschwe1lera subglandulosa (guatecare), Pantaclethra macroloba (bois mulatra or fineleaf), Maximiliana elegans (cocorite palm), and Mora excelsa (mora). The largest trees are buttressed, and many are 1rportant sources of food for wild animsls. The semf-evergreen seasonal forest exists where 50-70 1nches of ava1lable molsture occurs. It is an open forest characterized by " . . a discontinuous emergent layer at 60-80 feet, and an almost continuous layer at 20-40 feet" (Beard, 1946, p. 38). Lianas are very abundant, but epiphytes are not. Buttressed trees are rare. Common species are Bravasia Integerrima (j1gger-wood), and Hura crepitans (sandbox).

The third form of seasonal forest, the dec1duous, occurs in areas of 30-50 inches of avallable molsture. It 1 s characterized by having a continuous canopy at 10-30 feet, and a few emergent trees up to 60 feet in height.

The dry evergreen or littoral woodland formation occurs along the coastal strip which is exposed to continual wind off the ocean. 
Figure 4: The Pleistocene vegetation of Venezuela and Trinidad. (after Beard) 

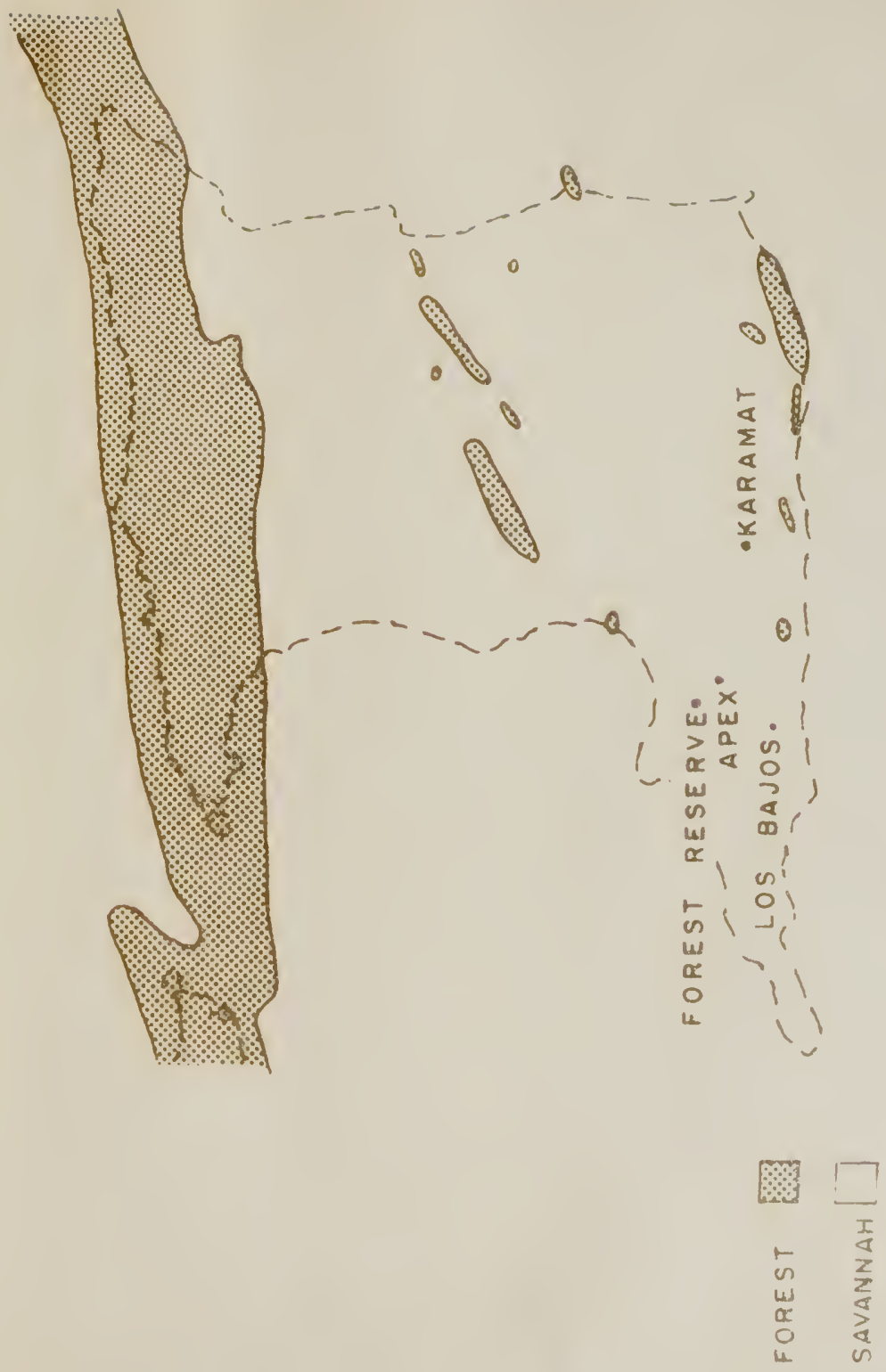
Figure 5: The pre-Columbian vegetation of Trinidad. (after Beard) 

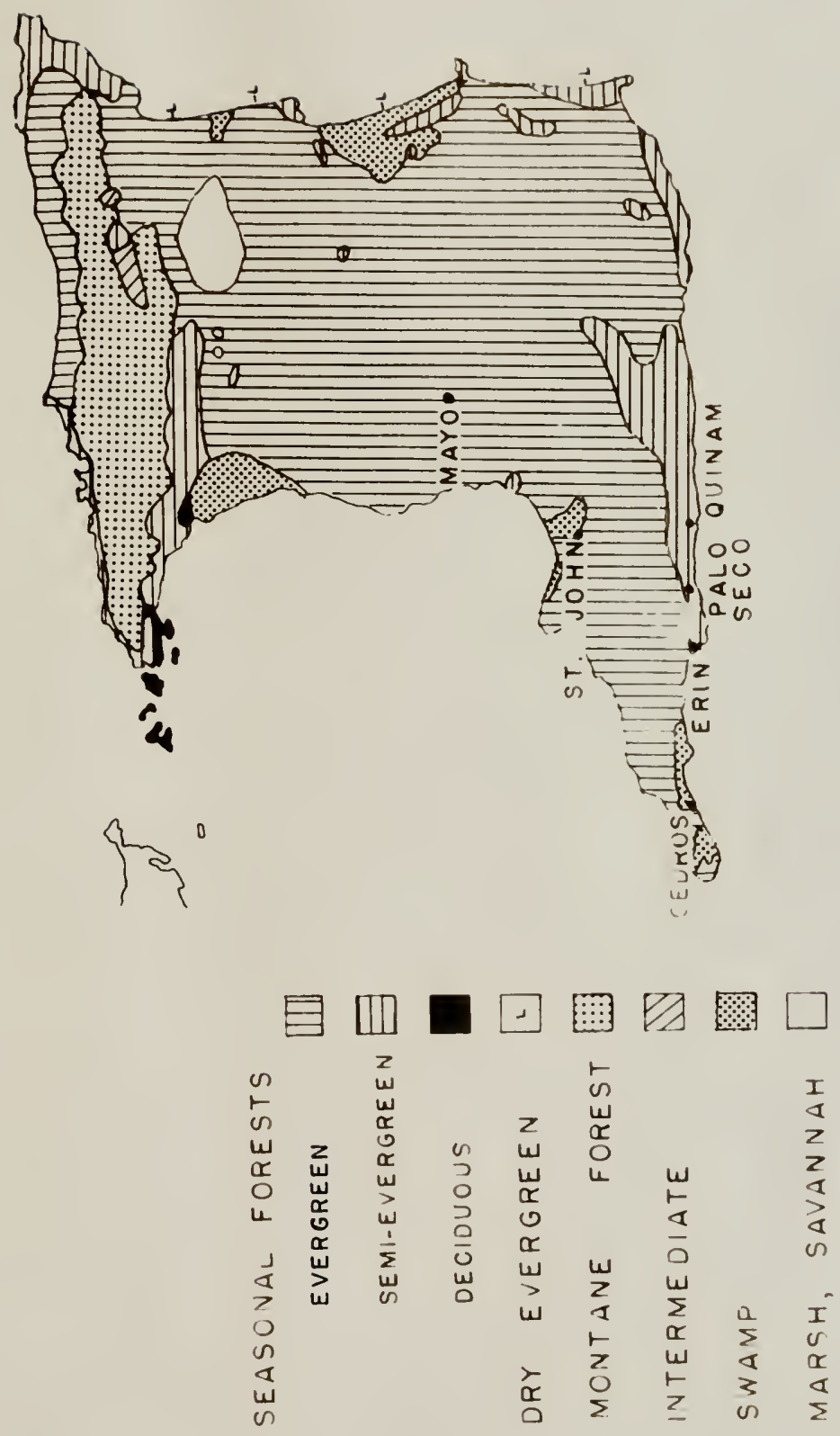
Two associations of this formation exist in Trinidad: the Coccoloba uv1fera-H1ppomane manclnella (sea grape-manch1neel), and Roystonea oleracea-Man1lkara b1dentata (palm1ste-balata).

Beard divides the montane formation into three association: lower montane rain forest, montane rain forest, and elf1n woodland. These replace one another at successively higher alt1tudes. The helght of the canopy decreases with increasing alt1tude, from 70-100 feet in the lower montane rain forest, to 60 feet in the montane forest, to 15-25 feet in the elfin woodlend.

The intermediate or seasonal montane formation is intermediate in characteristics between the seasonal and the montane formations. The swamp formation is composed of four types: swamp forest, palm swamp, herbaceous swamp, and mangrove woodland. The greatest area of swamp forest is the Oropouche swamp. In it the princ1pal tree species 1s Pterocarpus officinalis (swamp blackwood), which form a closed canopy at 60 feet and is conspicuously buttressed. The species of palm occurring in the palm swamps near the sea is Roystonea oleracea. The marsh formation consists of marsh forest, palm marsh, and savannah. The swamp and the marsh formations develop under the influence of particular edaphic factors. The marsh formation is characterized by only seasonal inundation and the swamp formation by permanent inundation. Savannahs of the marsh format1on are characterlzed by a dominant short bunch-grass, and a scattering of gnarled shrubs attaining a helght of up to 12 feet. Several specles of grasses occur, and the chief shrubs are Byrsonima crassifolla 
(savanna serratta) and Curatella americana (roughleaf) or Chrysobalanus pellocarpus (fat pork). These flre-resistant shrubs have in some areas replaced the former Myrcia-Roupala association which still occurs widely in the Venezuelan llanos.

The natural condition of the vegetation as sketched above has been markedly modiffed in recent times by the agricultural activities of man. About half of the Island 1s still forested. The land that is under cultivation was formerly principally seasonal forest. Cocoa and coffee are grown mainly in the North and Central Ranges, whereas sugar cane is grown in the flatter area between these ranges. Rice is cultivated in the swamp areas and coconuts along the cost, particularly the east coast. There has been some reforestation with teak in the southern watershed. 


\section{THE PRE-HUMAN MAMMALIAN FAUNA OF TRINIDAD}

The samples of the mammalian fauna from the three different time periods to be treated will be considered separately. The oldest perlod, represented by fossils, may be deslgnated the pre-human. The Recent fauna, representing two periods, is composed of Indian midden bones and of specimens from a period that may be termed the historic. The time range for the pre-human period includes the Pleistocene epoch and probably the early post-Pleistocene as well. A carbon-14 date of greater than 34,000 years has been determined from wood assoclated w1th Megatherlum remains at a depth of 12 leet at Trinidad's most important fossil locality at Forest Reserve, the so-called Glyptodon site. Durlng this time Trinldad was still broadly connected with the South American malnland, and savannah dissected by streams edged with gallery forest covered the area.

The pre-human fauna of Trinidad known at present is small, reflecting the limited amount of collecting carried out in thi: field. The fauna is represented by three orders: Edentata, Rodentia, and Proboscidea. The edentates are represented by the famllies Megatheri1dae, Mylodont1dae, and Glyptodontidae, the rodents by the Cricetidee, and the proboscidians by the Gomphotherlidae. All of these families, excepting the Cricetidae, are now extinct.

\section{Fossil Mammels of Trinided}

\section{Megatherildae}

Th1s family is represented by Megatherium amerlcanum Blumb., 
which has been found at several localities. An astragalus was found at Karamat mud volcano and Ident1fled by Schaub (1935). Parts of a skeleton were found at Los Bajos. The site at Forest Reserve also ylelded Megatherlum remains. Part of a tooth found at the time the Glyptodon skeleton was excavated (1957), and along with the other materials, was sent to the Amerlcan Museum of Natural H1story. In 1959 I found many dermal bones, a complete fourth tarsal, a complete tibia and flbula, part of a mandibular ramus, a rib, and three thoracic vertebrae. This fossil site is by far the most productive on Trinidad. It 1 a river bed cut to a depth of 15 feet into Mlocene sands and clays, and fllled with oll lmpregnated silt, sand, clay stone pebbles, plant remains ranging from large logs to twigs and stems, and vertebrate and insect fossils. This site is known locally as the "Glyptodon site."

\section{Mylodont1dae}

A single tooth of Mylodon sp. was excavated along with other materlals at the "Glyptodon site" and has been Identifled by me. It Is now deposited in the collection of the American Museum of Natural H1story.

\section{Glyptodontidae}

An almost complete Glyptodon skeleton, from which the "Glyptodon site" takes 1ts name, was found while the oll well site was beIng prepared in 1957. Almost the ent1re skeleton was found in place, and 1s now, unprepared, at the Amer1can Museum of Natural H1story. 
I found abundant dermal bone but no other skeletal parts while working at this site.

\section{Cricetidae}

At the "Glyptodon site" I found a layer with a concentration of small vertebrate remains two feet above the layers containing the large bones and logg. A single mammal was represented which is referable to the genus Zygodontomys. Assoc1ated w1th the Zygodontomys are unidentifled remains of a few birds, a turtle, a frog, and many insects. Another site containing small vertebrate fossils is at Apex near the "Glyptodon site" and geologically similar to it was found by Dr. Kugler. Zygodontomys sp., the only mammal represented, is assoctated with b1rd and 1nsect remains (Blair, 1927).

Named species of the genus Zygodontomys are distributed in northern South America and southern Central Amer1ca. Forms of Zygodontomys have been described from south of the Amazon River, from northeastern Braz1l and the Matto Grosso, but these are Included correctly in the genus Akodon (Tate, 1939). Tate (1939) divides the Zygodontamys 1nto two primary groups of small and large stze. Included in the group of large-sized species is Zygodontomys brevicauda, which occurs abundantly on Trinidad, and other species distributed in Panama and northern Colombia. The group of small-sized species include ones distributed in Central America, Colombia, Venezuela, and the Gulanas. Tate (1939) also reports that among the speclmens referable to Zygodontomys microtinus stellae from the Esmerelda savannahs at the foot of Mt. Dulde there are some Individuals 
with a normal upper molar tooth row of $4.2 \mathrm{~mm}$. and there are others with the shortest known tooth row of 3.7 to $3.8 \mathrm{~mm}$. for th1s genus. Gyldenstolpe (1932) notes that Zygodontomys thomas1 distributed in the Cumana district of Venezuela is allied to Zygodontomys brevicauda but 1s much smaller. The fossil Zygodontomys from Trinidad is also similar to Zygodontomys brevicauda but a great deal smaller.

Since the fossil material is largely fragmentary only a few measurements could be taken. The most useful ones were the alveolar length of the upper and lower cheek tooth rows. A comparable set of measurements was taken on Zygodontomys brevicauda from owl pellets found by $F$. W. Urich on Trinidad, Zygodontomys microtinus stellae from Esmeralda Savannah, Venezuela, and Zygodontomys thomss1 from Cristobal Colon, Venezuela. These were taken to the nearest one tenth of a m. and appear in Table 2.

The foss1l Zygodontomys differs from the other species of Zygodontomys avallable for comparison in several respects. The most outstandIng characteristic of the fossil form 1s 1ts small size (Table 3). Additional characteristics that distinguish the fossil are exceptionally long anterfor palatal foramina and deeply concave zygomatic plate. In the younger 1ndividuals (specimens with unworn teeth) the foramina extend posterlor to the level of the posterior lingual root of the first molar. In the oldest individuals of the fossil (w1th heavily worn teeth) and in young 1ndividuals of other species the foramina extend postertorad only to the anterior root of the first molar. Diagnostic dental characteristics include a deep anterior median fold in $\mathrm{M}^{2}$, a broad U-shaped 
TABLE 2

MEASUREREMTIS (IN MILLTMETERS) OF THE ALVEOLAR CHEEK TOOTH ROW OF VARIOUS SPECIES OF ZYGODONTOMYS

\begin{tabular}{|c|c|c|c|c|}
\hline & & Number & Mean & Range \\
\hline \multirow{2}{*}{ Zygodontomys sp. } & upper & 7 & 3.7 & $3 \cdot 3-4.1$ \\
\hline & lower & 24 & 3.6 & $3.1-4.3$ \\
\hline \multirow{2}{*}{ Z. thomss1 } & upper & 5 & 4.6 & $4.2-4.9$ \\
\hline & lower & 6 & 5.1 & $4.9-5.2$ \\
\hline \multirow{2}{*}{ Z. brevicauda } & upper & 13 & 5.1 & $4.7-5.6$ \\
\hline & lower & -- & - & -- \\
\hline \multirow[b]{2}{*}{ 2. microtinus stellae } & upper & 6 & 4.1 & $3.8-4.2$ \\
\hline & lower & 6 & 4.1 & $4 \cdot 0-4 \cdot 3$ \\
\hline
\end{tabular}




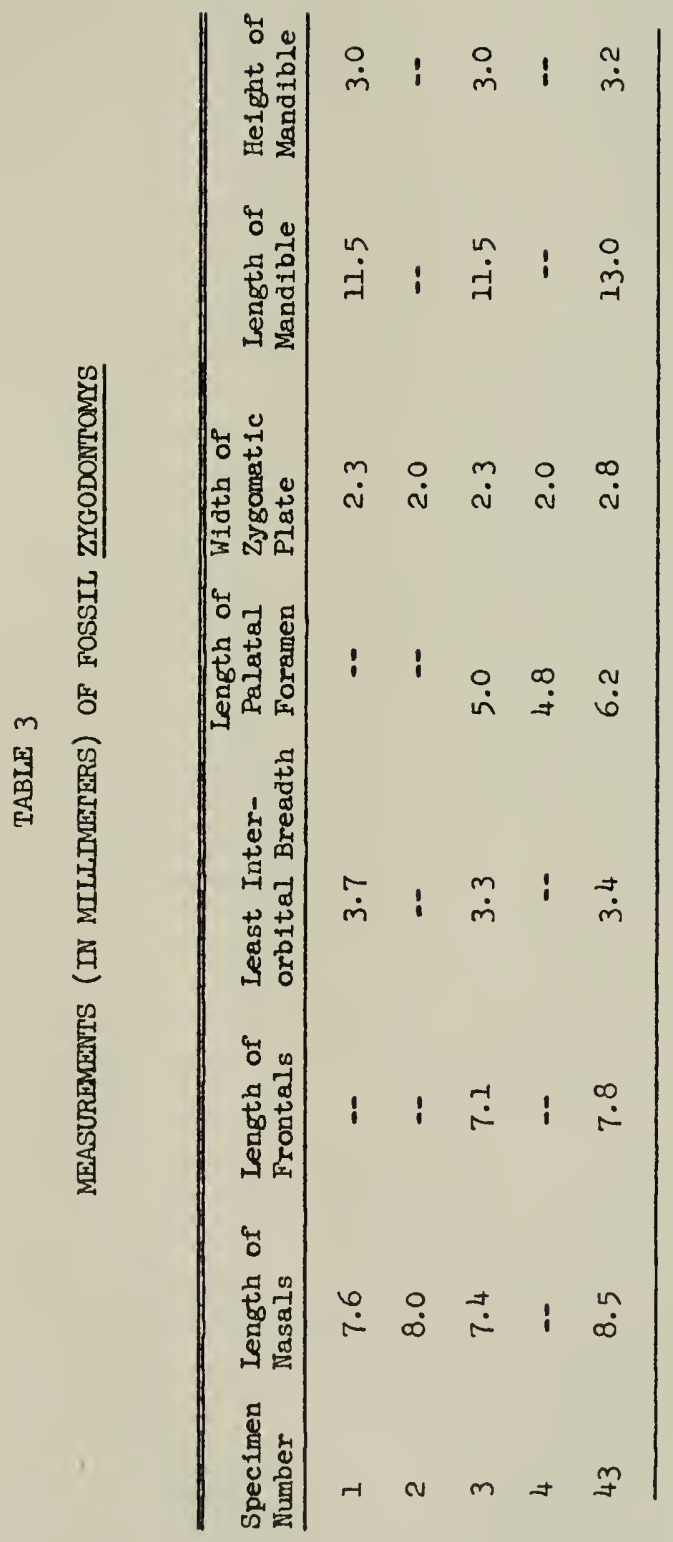


first primary fold, and presence of a mesostyle, anterior labial style, anterfor lingual style, or enterostyle in the $M^{1}$ and $M^{2}$. The anterior median fold is exceedingly well developed and is present in all spec1mens except those in wh1ch 1 t 1 s obliterated by excessive wear. Th1s fold 1s otherwise present in only a few specimens of Zygodontomys brevicaude and in these it is merely a vestige. The first primary fold is broed in the fossil specimens and narrow in the other species. In the $M^{1}$ the mesostyle is present in all of the specimens and the other three styles occur in between 64 percent and 73 percent of the 16 specimens. In the $\mathrm{M}^{2}$ the enterostyle is present in 78 percent of the nine specimens and the mesostyle in 67 percent. No styles are found in any of the other species. In the lower cheek tooth serles the mesostylid is present on the $\mathrm{M}_{2}$ in 94 percent of the 17 specimens. The articular process of the mandible is also distinctive, being short and broad, whereas in the other specles $1 t$ is long and narrow.

According to Tate (1939), "The South Amer1can Zygodontomys appear to be a grassland-inhabiting group of mice. I have little doubt they extend southward from Sucre across the llanos to the Orinoco and continue into Gulana wherever savannas ex1st." It appears, therefore, that when the llanos extended into Trinldad there was opportunity for the spread of this genus into Trinldad from South America.

\section{Gomphother11dee}

Cuvleronfus hyodon (Fischer) is represented by two teeth found at Ios Bajos and 1dent1fled by Schaub (1935), part of a tooth found orldinally at the "Glyptodon site," and another fragment of a tooth found by me at the same site. 
Zoogeographic S1gnificance of Pre-human Fauna

The known fossil faune of Trinldad is sparce in numbers of species. Further collecting will probably increase this number cons1derably. The Edentates are of South American or 1gin but the three genera, Megather1um, Mylodon, and Glyptodon, found in Trinldad were distributed throughout much of both North and South America in the Ple1stocene. Megatherlum ranged fram South Amer1ca to southeastern Unlted States in the Ple1stocene. Mylodon ranged from South Amerlca to southwestern United States and was contemporaneous with man. Glyptodon was apparently very numerous throughout South America and southern UnIted States in the Ple1stocene. Of the Proboscidea, the genus Cuvieron1us probably or1ginated In southwestern Un1ted States (Osborn, 1936) and was distributed widely in South America and in southern Narth America in the Ple1stocene. The rodent Zygodontomys evolved in South America and exists now in South Anerica north of the Amszon River and in Central America as far north as Costa Rica. Certain forms south of the Amazon River whlch have been referred to the genus are probably referable instead to the genus Akodon (Tate, 1939). All known representatives of the fossil fauna of Trinldad are herblvores and are characterlstic of grassland hab1tats, which were widespread in Trinidad during the Plelstocene. 


\section{MAMMALIAN FAUTA AS REPRESENTED IN INDIAN MIDDENS}

The present knowledge of the pre-Columblan mammalian fauna of Trinidad is based on skeletal material excavated from nine Indian sites. These sites represent all the cultural levels known on Trinidad. The sltes, like all those known from the 1sland, are located neer the coast, Indicating an orlentation of the people toward the sea. The pre-ceramic sites are, of course, the oldest, dating here from 2,750 ( \pm 130$)$ years ago. These are followed by sites exhlbiting four distinct ceramic styles (Bullbrook, 1953) that span the time from the pre-ceramic period to contact with the Span1sh after 1532 . The first of these periods is characterized by the Cedros style, the second by the Palo Seco style, the third by the Erin style, and the last by the Bontour style. Pottery of the last perlod is sometimes assoclated with Spanish ceramic work (Table 4).

\section{Description of Sites}

\section{St. John}

The St. John site is located on a high bluff south of the Godineau River above the Oropouche Swamp, and at the end of the St. John Road. Th1s location takes advantage of the evergreen seasonal forest on the hill and the mangrove swamp habitats. This site was excavated in 1953 by Drs. Rouse and Goggin (Rouse, 1953). The solls are light sands that are freely drained. The shell midden at this site 1 extensive, reaching four feet in depth and 125 feet in diameter. Material of two successive occupations has been obtained 


\section{TABLE 4}

CORRELATION OF PERIODS OF OCCUPATION ON TRINIDAD AND CERAMIC STYLES (after Cruxent and Rouse)

\begin{tabular}{cl}
$\begin{array}{l}\text { Venezuelan Periods of } \\
\text { Occupation }\end{array}$ & $\begin{array}{l}\text { Trinidad Ceramic } \\
\text { Styles }\end{array}$ \\
\hline V & $\begin{array}{l}\text { St. Joseph } \\
\text { IV }\end{array}$ \\
\hline Bontour \\
\hline$I I$ & Erin \\
\hline Palo Seco \\
\hline$I$
\end{tabular}


here. The first of these is pre-ceramic and is comparable to the Ortoire site, for which there is a carbon-14 date of about 2,750 years. The second period of occupation is characterized by pottery of the Bontour style, with some European ware. This excavation consisted of 13 level units, four of which were pre-ceramic, five protohistoric, and four a mechanical transition between the two. Each of these three groups of levels has approximately the same proportion of each mammal species in them, but the pre-ceramic group contains more bones (Table 5). This is probably the result of differences in the economy of the two cultures, the pre-ceramic population depending exclusively on hunting and fishing, while agriculture also contributed to the food economy of the protohistoric population. Another factor that might explain the difference in the relative quantities of bones and artifacts could be that in the ceramic sites a larger proportion of the bulkier artifacts would correspondingly reduce the number of bones found in a given area and level.

\section{List of Species Identified}

Didelphis marsupialis, opossum: 10 individuals.

Dasypus novemcinctus, nine-banded armadillo: 27 individuals. As in all other sites there is a far higher proportion of bone fragments to minimum number of individuals for the armadillo than for any any other mammal because of the numerous bones in the shell. On the average for every 4 to 5 individuals, there were over 75 armadillo bones identified, but fewer than 50 bones identified for the same number of any of the other mammals. 
TABLE 5

RETATIVE ABUNDANCE OF MAMMALS AT DIFFERENT TIME PERIODS WITHIN THE ST. JOHN SITE

\begin{tabular}{|c|c|c|c|}
\hline & Preceramic & $\begin{array}{l}\text { Mechanical } \\
\text { Transition }\end{array}$ & Protoh1storic \\
\hline Didelph1s & 3 & 3 & 4 \\
\hline Dasypus & 15 & 6 & 6 \\
\hline Alouatta & 5 & 3 & 2 \\
\hline Rhipidomys & 1 & & \\
\hline Coendu & 1 & 2 & 1 \\
\hline Agout 1 & 11 & 7 & 8 \\
\hline Dasyprocta & 4 & 3 & 6 \\
\hline Echimys & 2 & 1 & 1 \\
\hline Proech1mys & 9 & 2 & 1 \\
\hline Procyon & 1 & & 2 \\
\hline Lutra & & 1 & \\
\hline Felis & 1 & & \\
\hline Pecar1 & 27 & 18 & 12 \\
\hline Mazama & 10 & 7 & 7 \\
\hline
\end{tabular}


Alouatta sen1culus, red howler monkey: 10 individuals.

Rh1p1domys coues1: 1 individual.

Coendu prehensilis, porcupine: 4 1ndividuals

Agout 1 paca, paca: 26 1ndividuals in all; 8 in the proto-historic group of levels, and 11 in the pre-ceramic group. The remaining 7 were found in the levels of mechanical transition.

Dasyprocta egut1, agout1: 13 Individuals in all; 6 in the protohistoric group of levels, and 4 in the pre-ceramic group; 3 in the transitional group of levels. The paca and agout1 were represented numerously enough in all sites to allow useful comparison. Echinys armatus, spiny rat: 4 individuals.

Proechimys guyannensis, splny rat: 12 individuals.

Procyon cancrivorus, crab-eating raccoon: 3 individuals.

Lutra enudris, otter: 1 individual.

Felis pardalis, ocelot: 1 individual.

Pecar1 tajacu, collared peccary: 57 1ndividuals in all; 12 in the protohistoric group of levels, and 27 in the pre-ceramic group; 18 in the transitional group of levels.

Mezame americana, brocket: 24 individuals in all; 7 in the protohistoric group of levels, and 10 in the pre-ceramic group; 7 in the transitional group of levels. As with the paca and agout1, the peccary and brocket were sufficiently well represented at each site to allow comparison.

Other vertebrates: As at all other sites there were very few blrds represented, Cair1na moshata (muskovy duck) being 1dent1fied. 
There were a few land turtles, but no sea turtle remains at this site. Fish remains, particularly cat $11 \mathrm{sh}$, were abundant here as at all other sites.

2. Cedros

The Cedros site is situated on the United States Army's Green Hill Reservation in the extreme southwest corner of the island and is located on a slight elevation within one fourth mile of the sea. The area is now a coconut plantation and 13 inhabited; it was, however, formerly palm swamp surrounded by evergreen seasonal forest. The sandy soll in this area is classifled as having impeded drainage, since it is close to sea level and the water table. Cedros Is a shell mound ylelding purely Cedros style pottery. The materials studied were from an excavation made by $\mathrm{Dr}$. Rouse and $\mathrm{Mr}$. Bullbrook (Rouse, 1953), consisting of 25 level units, and from two random surface collections made by $\mathrm{Dr}$. Kugler and by me. The economy of this culture, as $1: 3$ true for $a l 1$ the ceramic cultures known on Trin1dad, was probably based on hunting, flshing, gathering, and agriculture.

\section{List of Species Ident1fled}

Didelphis mersupialis, opossum: 5 individuals.

Dasypus novemc1nctus, nine-banded armad1110: 15 Individuals.

Tamandua longlcaudata, ant eater: 2 1ndividuals.

Alouatta seniculus, red howler monkey: 1 individual.

Agout1 paca, paca: 16 ind1viduals.

Dasyprocta agut 1, agout1: 14 individuals. 
Proechimys guyannens1s, spiny rat: 1 individual.

Canis cf. familiaris, dog: 3 individuals. These were represented only in the surface collection, and were undoubtedly added in recent times.

Procyon cancrivorus, crab-eating raccoon: 2 individuals.

Herpestes auropunctatus, mongoose: 4 1ndividuals. This species, like the dog, was found only in the surface collection and was deposited in recent times.

Pecar1 tajacu, collared peccary: 14 individuals.

Mazama americana, brocket: 23 Individuals.

Bovid: I individue 1. This was found only in surface collections and was deposited in recent times.

Trichechus manatus, manatee: 2 lndividuals.

\section{Palo Seco}

The Palo Seco midden is on the south coast of Trinidad. It 1s located on a ridge at an elevation of 90 feet and is surrounded by hills. The shoreline 15 approximately 200 yards distance. The Palo Seco site is now at the center of the Trinldad Petroleum Development camp, but it was formerly in semi-evergreen forest habltat. The soils of this area are predominantly clays and silts with impeded drainage. The excavation, made by Dr. Rouse (Rouse, 1953) at this site consisted of 57 level units, and yielded two pottery types, Cedros and Palo Seco. 


\section{List of Species Identified}

Didelph1s marsuplal1s, opossum: 14 individuals.

Dasypus novemcinctus, nine-banded arnadillo: 18 individuals.

Tamandua longlcaudata, ant eater: 2 individuals.

Alouatta seniculus, red howler monkey: 3 individuals.

Coendu prehensilis, porcupine: 6 individuals.

Agout paca, paca: 41 Individuals.

Desyprocta agut1, agout1: 47 individuals.

Proechinys guyannens1s, spiny rat: 2 individuals.

Felis pardalis, ocelot: 1 1ndividual.

Pecar1 tajacu, collared peccary: 26 individuals.

Mazama americana, brocket: 76 individuals.

Bovid: 1 1ndividual. Th1s was found at the surface, presumably

from recent occupation.

Tap1rus sp., tapir: I individuel. A right lower second pre-molar was found. This animal occurs on the mainland of South America. Trichechus manatus, manatee: 1 individual.

Cetacean: 1 individual.

Other vertebrates: Sea turtle remains were abundant at this site and at the other south coast site. There were few or no remains of land turtles.

\section{Erin}

The Erin midden 1s just west of Palo Seco in the center of the town of Erin under the present police station. It is on a hill that was covered with semi-evergreen forest, about one-half mile from the 
beach and the Erin River. The soils here, as at Cedros and Palo Seco, are poorly drained clays and silts. The site yielded Palo Seco and Erin style pottery. The materials that were examined came from an excavation made by Dr. Rouse (Rouse, 1953) that consisted of 69 level units, and one excavation made by Mr. Bullbrook, in which, however, the specimens from different levels were not kept separate.

\section{List of Species Identified}

Didelphis marsuplalis, opossum: 18 individuals.

Caluromys philander, woolly opossura: 2 individuals.

Dasypus novemcinctus, nine-banded armadillo: 10 individuals.

Tamandue longicaudata, ant eater: 2 individuals.

Alouatta seniculus, red howler monkey: 3 individuals.

Sclurus granatensis, squirrel: 1 individual.

Nectomys squamipes: I Individual.

Coendu prehensilis, porcupine: 4 individuals.

Agout1 paca, paca: 14 individuals.

Dasyprocta agut1, agout1: 59 individuels.

Echimys armatus, spiny rat: 2 individuals.

Proechinys guyannensig, spiny rat: 2 individuals.

Canis cf. Pamiliaris, dog: 1 1ndividual. This came from a surface level.

Procyon cancrivorus, crab-eating raccoon: I individual.

Lutra enudris, otter: 1 individual.

Felis pardalis, ocelot: 2 Individuals. 
Herpestes auropunctatus, mongoose: I 1ndividual. Th1s came from Mr. Bullbrook's collection and presumably was collected from the surface.

Pecar1 tajecu, collared peccary: 11 individuals.

Mazama amer1cana, brocket: 61 individuals.

Trichechus manatus, manatee: 1 individual.

\section{Mayaro}

This site is just back of the Atlant1c coast shore in a coconut grove belonging to the St. Bernard Estate, a short distance directly south of Cape Mayaro. The ceramic style at this site is predominantly Palo Seco. The bones avallable for study consisted of two small surface collections, one made by Dr. J. Hill of Port-ofSpain and the other by me, both in 1959.

\section{Ilst of Spec1es Identified}

Desypus novemc1nctus, nine-banded armad1llo: 2 1ndividuals.

Agout1 paca, paca: I Individual.

Dasyprocta agut1, agout1: 1 1ndividual.

Proech1mys guyannens18, spiny rat: 1 1ndividual.

Pecarl tajacu, collared peccary: 3 1ndividuals.

Mazama amer1cana, brocket: 2 1nd1viduals.

\section{Quinam}

The Quinam midden is located in sem1-evergreen forest east of the Palo Seco site, near the beach and the Palmiste River. The soll is similar to that of Erin and Palo Seco. The excavations made 
by Dr. Rouse (Rouse, 1953), consisting of 58 level units, produced pottery of Pelo Seco, Erin, and Bontour styles.

\section{L1st of Species Identifled}

D1delph1s marsupieils, opossum: 4 1ndividuals.

Dasypus novemcinctus, nine-banded armadillo: 10 1ndividuals.

Tamandua longlcaudata, snt eater: 2 indiv1duals.

Alouatta seniculus, red howler monkey: 2 individuals.

Agout1 paca, paca: 16 1nd1v1durls.

Dasyprocta agut1, agout1: 26 1nd1v1duals.

Lutra enudris, otter: 1 Individual.

Felis pardal1s, ocelot: 2 individuals.

Pecrr1 tajacu, collared peccary: 23 1ndividuals.

Tayassu pecar1, white-l1pped peccary: 5 1ndividuals. Th1s was the

only site where remains of this specles were found.

Mazama americana, brocket: 77 Individuals.

\section{Chagonaray}

Th1s site 1s half way between Palo Seco and Quinam on Chagonaray Polnt. It has quite the same ecological conditions as Quinam, but 1s undergoing coastal erosion. The pottery found was principally of Erin and Bontour style, but also included some of the Barrancas style typical of the Lower Orinoco region (Rouse, personal communication). The mammal material examined was from a surface collection made by me. 


\section{List of Species Identified}

Dasypus novemcinctus, nine-banded armad1110: 1 individual.

Agout1 paca, paca: 1 individual.

Dasyprocte agut1, agout1: 1 individual.

Proechinys guyannens1s, spiny rat: I individual.

Pecar1 tajacu, collared peccary: 3 1ndividuals.

Mazama americana, brocket: 2 individuals.

\section{Mayo}

Mayo is a Spanish mission site located in the Montserrat H1lls of the Central Range, seven m1les from the Gulf of Paria. A Catholic church has been built over the s1te. Formerly this area was covered by evergreen seasonal forest. The soll is light and freely drained. On the basis of the Bontour style pottery and the European ware found, this site has been dated (Goggin, personal communication) from the late seventeenth or early elghteenth centuries. The material examined came from an excavation of 8 level units made by Dr. Gogg1n (Rouse, 1953) and from my surface collect1on.

\section{List of Species Identifled}

Dasypus novemcinctus, nine-banded armad1110: 14 individuals. Tamandua longicaudata, ant eater: 3 individuals. Alouatta sentculus, red howler monkey: 6 individuals. Coendu prehens1lis, porcuplne: 2 individuals. Agout 1 paca, paca: 12 individuals. Desyprocta agut1, agout1: 5 indiv1duals. 
Canis cr. familiaris, dog: 1 individual.

Pecari tajacu, collared peccary: 17 individuals.

Mazama americana, brocket: 8 individuals.

9. St. Joseph

St. Joseph was the first Spanigh capital of Trin1dad, and the site is located in the town of St. Joseph on a branch of the Caronl River on the south side of the North Range. This area was sem1-evergreen forest. The excavation made by $\mathrm{Dr}$. Rouse and $\mathrm{Dr}$. and Mrs. Goggin (Rouse, 1953), consisting of 13 level units, ylelded Bontour style pottery and European ware.

\section{List of Species Identified}

Coendu prehens111s, porcupine: 1 individual.

Agout1 paca, paca: 1 individual.

Dasyprocta agut 1, agout1: 3 individuals.

Mazama americana, brocket: 2 individuals.

Bovid: 2 1ndividuals.

Cetacean: 1 individual. 


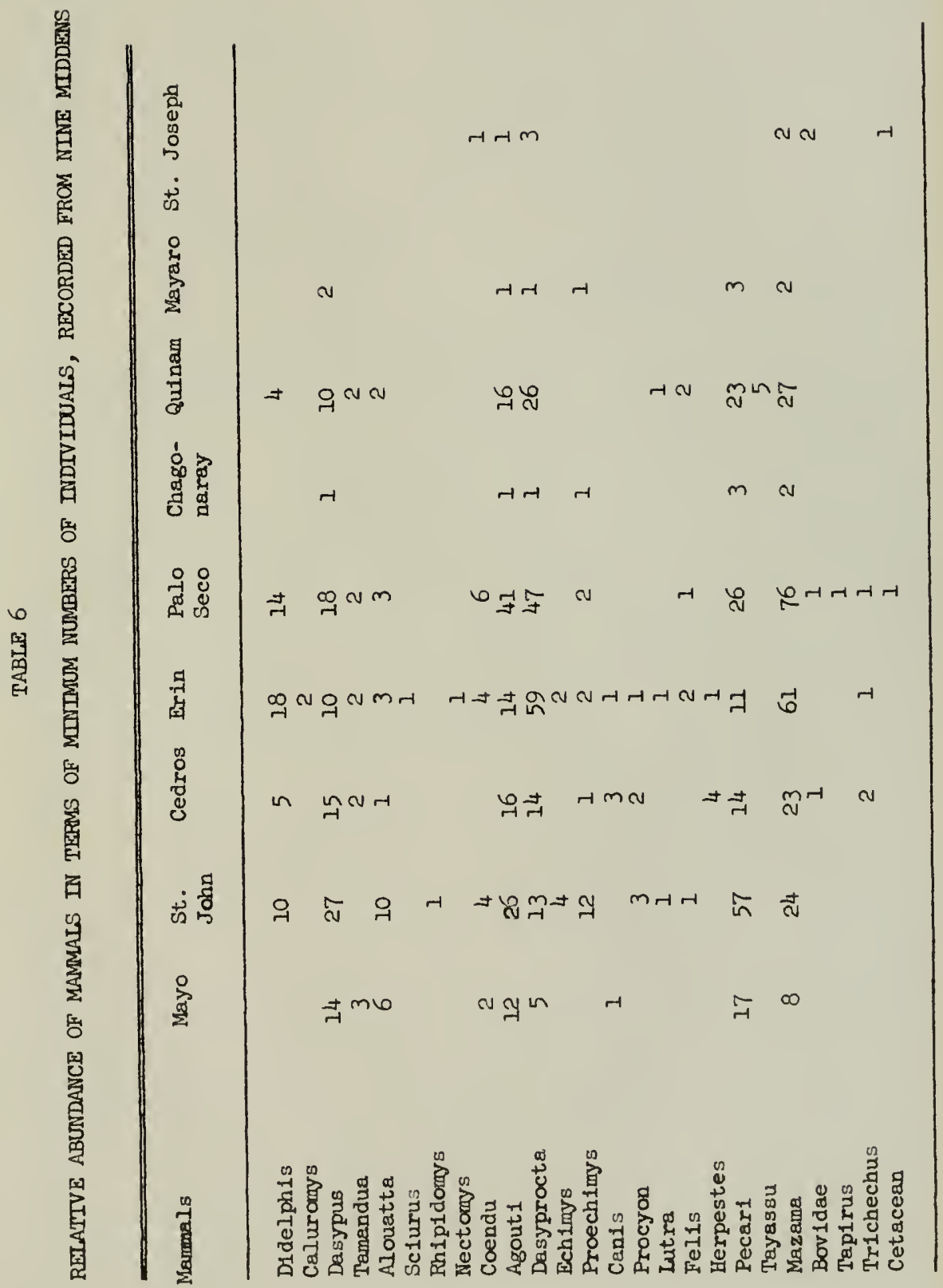




\section{Intersite Comparisons}

The manmals that have been Identifled from Indian middens comprise a surprisingly complete list of the larger animals found In Trinidad today. One group of animals that 1s, however, entirely missing is the bats, although there are a great number of bats (Goodwin and Greenhall, 1961) now IIving on Trin1dad. Another group, the cricetid rodents, is represented in the middens only by the two largest genera, Rhipldomys and Nectomys. Of the four species of marsupials now occurring on Trinldad, two species of the genus Marmose were not found in the middens. Presumably the bulk of the animals represented were used by the Indians for food. This automatically excludes from the middens a certain portion of the natural fauna of the area, either because the Ind1ans would make no effort to catch animals they considered useless, or because they might not have the technological abllity to catch otherwise edible forms. Thus, for example, although there seems no reason to suppose that the bat population on Trinldad was markedly inferior to that at the present time, it is not wholly surprising that no bat remains are to be found in the middens.

The smallest animal represented in the middens is Rhipldomys. With three exceptions, all larger animals now known from Trinidad occur In the middens. One of those not represented is the small arboreal anteater, Cyclopes didactylus. This animal, aside from being relatively small, emits a very mournful wall, which may have caused it to be avolded. The capuchin monkey, Cebus albifrons, was also not found. This spectes has a large gap in its distribution on the mainland, and 
the closest ally to the Trinidadian form occurs around the Maracaibo Basin in eastem Venezuela and nowhere in the area closer to Trinidad. Hershkov1tz (1949) has suggested two possible explanat1ons for 1ts appearance on Trinldad: that Cebus albifrons may at an earlier time have had a wider distribution than it does at present, or that it was brought to Trinidad by early inhabitants as a pet. In regard to the second of these suggestions, It seems highly doubtful that, had the monkey been kept about the camps, no remains of it would be found. The absence of this species from the midden material does not, however, seem necessarily to invalidate the first suggestion that it was indigenous to Trin1dad. Possibly the explanation lies in the fact that the monkey is of relatively small size, and may have been undesirable as an article of food. The third animal which might have been expected but was not recorded is the tayra, Elra barbara. However, remains of it have been recorded by Bullbrook (1953) from his excavations at Palo Seco. Remains of two other large animals which may exist on Trinidad-the coat1-mund1, Nasua, and the water opossum, Ch1ronectes--were also absent from the middens. Probably individuals of these species find their way over from the mainland from time to time. Mr. I. Wehekind (personal comunication) has informed me that the cost1-mundi possibly occurs in the North Range. There is a somewhat better record of the water opossum (Greenhal1, 1956) based on a photograph, and the descrlption of a strange opossum shot by a hunter in Guayaguayare at the southeastern tip of Trinidad. The absence of remains of these animals in the middens, taken together with their present status on Trinidad, would 
seem to indicate that in the past as now they were either merely occaslonal visitors to the 1sland, or, if native, so rare as to be of no consequence to the fauna.

Only one mamal not previously reported from Trinidad was represented in the midden samples. This is the tapir, Tapirus, of which the remains found consisted of a single premolar. The tapir now exists on the mainland, and it is quite concelvable thet the tooth found at Palo Seco was brought there by man. The white-11pped peccary, Tayassu pecar1, has been reported from Trinidad, but it 18 questionable whether it still exists there or ever did in cons1derable numbers. Rema1ns of 1t were Pound at Quinam. Another mammal, the savannah deer, Odocolleus gymnot1s, which does not at present occur on the 1sland, was 1dentified from the Erin midden by $D_{r}$. S. Schaub, according to a personal communication by Dr. Kugler. I found no remalns of this animal, however.

The surface levels at the Cedros, Palo Seco, and Erin sites contained remains of introduced animals that were probably deposited at the site subsequent to occupation by the Indians. Each of these sites is in a populated area, making this supposition even more likely. At Mayo and St. Joseph, as a result of colonial contact, these introduced forms were incorporated in the middens. Bovid remains appear in the Cedros, Palo Seco, and St. Joseph Middens. The mongoose, Herpestes a. auropunctatus, that was introduced Into Trinidad in 1870, occurred in the Cedros and Erin sites. Remains of a small dog, Canls famillaris, were found at Mayo and Cedros. 
In Trinidad, considering all sites together, 25 species of mammals are represented (Table 6). Much can be learned from those species which were caught in sufficlent quantities to make them, on the bas1s of the evidence of the remains found in the middens, the chief sources of meat in the Indian's diet. In every site, the five most abundant species were the armadillo, Dasypus novemcinctus; paca, Agout1 paca; agout1, Dasyprocta agut1; collared peccary, Pecar1 tajacu; and brocket, Mazama americana. These f1ve forms make up more than 75 percent, in number of 1nd1viduals, of the an1mals at each of the sites. The Incidence of these forms at the six largest sites was analyzed statistically for randomness by a contingency table. The results $\left(x^{2}=115.09,4\right.$ degrees of freedom) show that the observed differences are highly significant. There are two possibilities to explain this difference; elther food preference by the Indians or the local animal population. Since here is no cultural evidence to indicate a difference in food preference, the conclusion that 18 drawn is that the three smaller ones, the armad1llo, paca and agout1, and the two larger ones, the peccary and the brocket, were probably equally sought. Therefore, the relative abundance of each at the different sites probably reveals their actual abundance in each area rather than selection by the Indians. At the three south cosst sites of Quinam, Palo Seco, and Erin, the percentage of armadillo among the mamols represented within each site is one half or one thlrd as great as within the sites of Mayo, St. John, and Cedros (see Table 6). This diatribution may well be correlated with the soll best suited to the burrowing activity of the armadillo. 
At the three south coast sites, the solls are predominantly clays and silts with relatively poor dralnage. Thus soll conditions would not be as favorable for burrowing as light solls with free dreinage or excessive drainage found in the area of the Mayo and St. John site. The sandy soll at the Cedros site, although classifled as having impeded dralnage because it 1 ; close to sea level and the water table, would, however, provide suitable substrate for burrows. The evidence suggests, therefore, that the relative abundance of these animals is related to the character of the soll as indicated by midden remains.

The relative abundance of agout1 and paca at the various sites would also appear to be correlated with the ecology around each site. At the two sites in the denser evergreen seasonal forest--Mayo and St. John--paca were found to be approximately twice as abundant as agout1, whereas the reverse was found to be true at the three sites--Er 1n, Palo Seco, and Quinam--located in more open semi-evergreen forest. At Cedros near evergreen forest, but actually in palm swamp, paca and agout 1 remains are almost equally abundant. The paca is characteristically a forest animal, feeding on fruits and eggs laid on the ground, although it does venture into the edge of clearings as well. The agout 1 is usually found in more open forest.

A simliar pattern is seen when the relative abundance of deer and peccary remains are compared. At the Mayo and St. John sites, the remains of peccary are more than twice as abundant as those of deer, whereas at the Frin, Palo Seco, and Quinam sites, deer are almost three times as abundant as peccary. At the Cedros site also, more deer than peccary 
remains were found. The Quinam site revealed a few bones referable to the white-lipped peccary, Tayassu pecari, as well as remains of the collared peccary. Peccary are often found in forested areas, and part1cularly along river bottoms, where their feeding hablts are similar to those of pigs (Seton, 1929, quoting Audubon and Bachmen). Ideal habitat of this kind is present at the St. John site. This habitat was also found at Mayo with the Mayo River providing the river bottom conditions. Deer, although numerous in densely forested areas, prefer the open forests found along the south coast.

With the exception of the St. John site, which is a special case, no slgnificant trends in the numbers of individuals of a given species at different levels of excavation in the other sites could be discovered. Moreover, when the faunas from the various Indian middens are compared on the basis of the total fauna rather than by levels, no striking differences are found in their composition. Anlmals that are found only in a few sites appear to be incldental, and are represented by only a bone or two. As has been noted, differences in the faunas can be observed In the relative abundance of certain forms which were locally numerous and presumably equally sought after by the Indians. 
HISTORIC MAMAL FAUNA

One of the first lists of Recent mammals of Trinidad was published by De Verteuil (1884). It included 24 species of large, conspicuous land mammals. Three of these--Gulo, Viverra vittata (= Grison vittata), and Cachicamus septemcinctus (= Dasypus septemcinctus)--have since been found not to occur on the 1sland. De Verteull's I1st was followed in 1892 by a preliminary list of 24 species published by Oldfield Thomas. This number of species was enlarged by the work of J.A. Allen and F. M. Chapman whlch was based on material collected in Trinidad by Chapman in 1893 and 1894. In their first publication (1893), these authors 11sted 37 land mammals, 13 of which had not been previously reported. New species that were described included Nectomys palmipes (Holochilus squamipes listed by Thomas is later symonymized with this), Tylomys couesi, Oryzomys spec1osus, Oryzomys trinitatis, Oryzomys velut1nus, Oryzomys brevicauda, Loncheres castaneus, and Echimys trinitatis. In the second paper (1897) they omitted Myrmecophage jubata, Choloepus didactylus, Cercoleptes caudivolvulus, Loncheres castaneous (= Lcncheres guianae = Echimys armatus), and Dicotyles labiatus (= Tayassu pecar1). However, recent evidence has been obtained to indicate that the last two forms do, In fact, occur on Trinidad. Allen and Chapman also added the following species: Oryzomys delicatus, Akodon frustrator, and Thylamys carr1. The most recent list of Trinidad mammals is that of Vesey-F1tzgerald (1936), while the Chiroptera have been dealt with in a monograph by Goodwin and Greenhall (1961). 
One form included in the Vesey-F1tzgerald list, Akodon fru trator, ev1dently was described from a juvenile specimen of Zygodontomys brev1cauda, and had earlier been synonymized (Gyldenstolpe, 1932). A second species given, Oryzomys brevicauda, had previously been referred to the genus Zygodontomys (Gyldenstolpe, 1932).

A 11st of the Recent land mamrals of Trinldad 1s presented below. Although by far the largest segment of the mammal fauna of the 1sland 1s made up of bats, 58 specles having been reported, the Chlroptera are not included in the following list, since they have been the subject of a very recent monograph, and are of comparatively little importance archeologically. The list is essentially that of Vesey-Fitzgerald except for the addition of two specles, and certain nomenclatural changes. Most of the nomenclatural changes follow the work of Hershkovitz (1947, 1948, 1949, 1955, 1960) and Cabrera (1957). The synonyna for the spectes concerns only the references to the occurrence of these spectes on Trinldad. The list includes observations that I made during the summer of 1959.

\section{L1st of Terrestrial Mammals}

Didelphis marsuplalis 1nsularis Allen, Bull, Amer. Mus. Nat. H1st., XVI, 1902.

D1delphys marsuplal1s Thomas, Jour. Trinidad Fleld Nat. Club, I, 1893.

Dydelphis marsupialls Allen and Chapman, Bull. Amer. Mus. Nat. H1st., v, 1893. 
Didelphis karklnophaga Allen and Chapman, Bull. Amer. Mus. Nat. H1st., IX, 1897.

The opossum or "Manfcou" appears to be quite common, particularly around plantations. One male was shot on 3 September 1959 on a cocoa estate in the North Range, Arima Valley, Spring H1ll Estate. Its measurements were 744-399-55-En 48. Mango, insect and rodent remains were contained in the stomach. One skeleton from Biche was obtained from a bunter.

Caluromys philander trinitatis (Thomas)

Didelph1s (Ph1lander) philander Allen and Chapman, Bull. Amer. Mus. Nat. H1st., V, 1893.

D1delphis (Ph1lander) trin1tat1s Thomas, Ann. and Mag. Nat. H1st. (6) XIII, 1894.

"Manicou gros-yeux" is also quite common around plantations. One male was shot on 3 September 1959 at Spring Hill Estate. The measurements were 536-322-34-En 30. H1s stomach contained frult and lnsect remains.

Marmosa robinson1 chapman1 Allen

Didelph1s (Miscoureus) murina Allen and Chapman, Bull. Amer. Mus. Nat. Hist., v, 1893.

Marmosa murina Allen and Chapman, Bull. Aner. Mus. Nat. Hist., IX, 1897.

Marmosa chapman1 Allen, Bull. Amer. Mus. Nat. Hist., XIII, 1900.

One Immature male was trapped on 31 July 1959 at the base of a large clump of bamboo at Pointe-a-P1erre. H1s measurements were 192$111-14$. 
Marmosa carr1 (Allen and Chapman)

Thylamys carr1 Allen and Chapman, Bull. Amer. Mu . Nat. H1st., IX, 1897.

Marmosa carr1, in Trouessart Cat. Mamm. viv. foss. Suppl. 856.

Aloustta seniculus insularis Ell1ot

Mycetes seniculus (Linn.), Allen and Chapman, Bull. Amer. Mus. Nat. H1st. , IX, 1897.

Alouatta seniculus 1nsular1s Ell1ot, Ann. and Mag. Nat. H1st. Ser. 8, v, 1910.

Howler monkeys were often heard in the late afternoon or before rain at Guayaguayare. They were usually in bands of 3 to 10, each band appearing to have a fixed route through the forest. We observed a small band, composed of several adults with at least one young of that season, feeding on Mora flowers at Guayaguayare on 26 August 1959. One young male of th1s band was shot. H1s measurements were 1214-651-155-En 30 . Hog plum seeds were contalned in his stomach and intestine. Two skulls were found on the trall to La Table in Guayaguayare on 26 August 1959. Cebus albifrons trinitat1s Pusch

Cebus sp., Thomas Trinidad Field Nat. Club I, 1893.

Cebus apella, Vesey-Fitzgerald (nec. Linnaeus), Trop1cal Agr. (Trin1dad), 13(6), 1936.

Cebus alb1frons trin1tat1s Pusch, Ze1tschr. für Säuget, 16, 1941. Capuch1n monkeys move in large bands, 15 or more. They w1ll come quite close to 1nvestigate a call. One band attracted in such a way was seen in Guayaguayare forest. One male spec1men, formerly a pet, 
w\&s obtained from the Trinidad Reglonal V1rus Laboratory. Its measurements were $810-404-123-$ En 35 .

Tamandua longlcaudata long1caudata Wagner

Tamandua tetradactylus (Linn.), Allen and Chapman, Bull. Amer. Mus. Nat. H1st., V, 1893.

Tamandue long1caudata Wagner, Vesey-Fitzgerald, Troplcal Agr. (Trinidad), 13(6), 1936.

One ant eater or "mataperro" was shot at Guayanguayare on 27 August 1959. A partial skeleton was found on the trail to La Table on 26 August 1959.

Cyclopes didactylus d1dactylus (Linn.)

Cyclothumus didactylus (Linn.), in Allen and Chapman, Bull. Amer. Mus. Nat. Hist., V, 1910.

Cyclopes didactylus didactylus (Linn.) in Vesey-F1tzgerald, Tropical Agr. (Trinidad), 13(6), 1936.

Dasypus novemc1nctus novemcinctus Linn.

Tatusia novemclnctus (Linn.) In Allen and Chapman, Bull. Amer. Mus. Nat. H1st., V, 1910.

The armadillo or "tatou" is widely distributed and common. It is the most common large mammal in the Mora forest of southeastern Trin1dad according to hunters. One male was shot on 31 August 1959 in Guayaguayare with measurements of 813-385-91- In 30. Three more individuals were shot in the same area on 27 August 1959. An 1mmature female was run down in the cocoa at Spring H1ll Estate, 13 August 1959, with measurements of 670-345-80-an 37 . 
Sclurus granatens1s chapman1 Allen

Sclurus aetuans hoffmani Peters, in Allen and Chapman, Bull. Amer. Mus. Nat. H1st., V, 1910.

Sclurus chapman1 Allen, Bull. Amer. Mus. Nat. Hist., XII, 1899. These are fairly common.

Nectomys squamipes palmipes Allen and Chapman

Holoch1lus squamipes (Brants) in Thomas, Jour. Trinidad Field Nat. Club I, 1893.

Nectomys palmipes Allen and Chapman, Bull. Amer. Mus. Nat. Hist., V, 1910.

These are commonly found at the edge of ponds or streams. Two were trapped at the edge of a shallow pond in a logged area and one was shot along a stream in Guayaguayare forest. The two males were both in breeding condition and were caught the 29 and 30 August 1959. They measured 437-220-51-En 23, 346-177-45-En 21, respectively. One pregnant female with three embryos wh1ch averaged $27 \mathrm{~mm}$. crown-rump was caught the 31 August 1959 with measurements of 340-183-45-En 20 . Oryzomys concolor speciosus Allen and Chspman

Oryzomys speciosus Allen and Chapman, Bull. Amer. Mus. Nat. H1st., V, 1910.

Oryzomys trinitatis Allen and Chapman, Bull. Amer. Mus. Nat. Hist., v, 1910.

One pregnant female with two very early embryos was trapped at Polnte-a-Plerre on 28 July 1959. Its measurements were 241-136-23. 
Oryzomys laticeps velutinus Allen and Chapman

Oryzomys velutinus Allen and Chapman, Bull. Amer. Mus. Nat. Hist., V, 1910.

Three were trapped between 13 and 16 August 1959 at Spring Hill Estate between the cocol and the uncleared land. There were some gnawed cocos pods on the ground. One female was a subadult, one was in breedIng condition, and one was pregnent with six embryos of which one was resorbing. The measurements were 163-75-24- $\operatorname{En} 16,210-109-27-\operatorname{Bn} 18$, 207- injured tall 87-28-an 20, respectively. Oryzomys (Oligoryzomys) delicatus Allen and Chapman

Oryzomys dellcatus Allen and Chepman, Bull. Amer. Mus. Nat. Hist., IX, 1897 .

Twelve skulls and 52 raml of this species were found in owl pellet material. This form is rare in collections. Rhipldomys couesi (Allen and Chapman)

Tylomys coues11 Allen and Chapman, Bull. Amer. Mus. Nat. Hist., V, 1893.

Rh1pldomys coues1 (Allen and Chapman), Bull. Amer. Mus. Nat. Hist., IX, 1897 .

Zygodontomys brevicauda brevicaude (Allen and Chapman)

Oryzomys brevicauda Allen and Chapman, Bull. Amer. Mus. Nat. H1st., v, 1893.

Akodon frustrator Allen and Chapman, Bull. Amer. Mus. Nat. Hist., IX, 1897. 
Forty-three skulls are represented in the owl pellet material. This form is commonly trapped.

Akodon urichi Allen and Chapman

Abrothrix caliginosus (Tomes), provisional reference in Allen and Chapman, Bull. Amer. Mus. Nat. Hist., V, 1893.

Akodon urich1 Allen and Chapman, Bull. Amer. Mus. Nat. H1st., IX, 1897.

S1gmodon cf. hirsutus

Twenty-one skulls referable to S1gmodon are represented in the owl pellet material. All the owl pellets studied were collected by the late F. W. Urich at St. August1ne, to the best of everyone's knowledge. St. Augustine is located elght miles east of Port-of-Spain and the Gulf of Paria and 35 miles from the nearest point on the mainland. Both the numbers of animals represented and the distance from the mainland would suggest that, if the owl pellets were indeed collected at St. Augustine, these rats must have been caught on Trinldad and as such represent a new record. Only minor differences were noted when they were compared with four skulls referred to S1gmodon h1rsutus. Three of these S1gmodon h1rsutus came from Caracas and one from Rancho Grande which is the closest record of this species to Trinidad. S1gmomys, characterized by grooved upper inclsors, has a range nearest to Trinidad. Hershkovitz (1955) suggests that probably all species of S1gmodon and S1gmomys are synonymous with S1gmodon h1sp1dus. This materlal tends to support the Idea that at least the skulls from Trinidad, the four skulls studied from Venezuela, and the skulls studied of S1gmodon h16pldus from Florida 
are very close. Some measurements taken on the skulls from Trintdad are given in Table 7 .

Heteromys anomalus anomalus (Thompson), in Thomas, Trin1dad Field Nat. Club I, 1892.

These are commonly trapped.

Rattus rattus (LInn.)

Flve were trapped in areas under cult1vation, inhabited areas, and in the deop forest. One was from Polnte-a-Plerre, two were from Sprlag H1Il Estate, and two were from Guayaguayare.

Rattus norveg1cus (Berkenhout)

Mus musculus Waterhouse

Coendu prehens1lis (IInn.)

Synetheres prehens1l1s (Linn.), in Allen and Chapman, Bull. Amer.

Mus. Nat. Hist., V, 1893.

A skeleton was obtalned from a specimen k1lled about 10 August 1959 In Guayaguayare and a jaw of another was found. Another skeleton was obtained from a hunter from Biche.

Agout 1 paca (Linn.)

Coelogenys paca (Ilnn.), in Allen and Chapman, Bull. Amer. Mus. Nat. H1st., V, 1893.

Paca or "Lappe" is a delicacy and as a result have become very rare. It and the peccary are probably the most difficult game animal to obtain in Trinldad. A skeleton of one was procured from a hunter from B1che. 


\section{TABLE 7}

MEASUREMENTS (IN MILLTMETERS) OF SICMODON CF. HIRSUTUS

\begin{tabular}{lccc}
\hline Measurement & Number & Mean & Range \\
\hline Skull length & 1 & 36.6 & \\
Zygomat1c breadth & 3 & 20.0 & $19.5-20.6$ \\
Interorb1tal breadth & 18 & 5.9 & $5.5-6.3$ \\
Length of pelate & 16 & 6.9 & $6.3-7.7$ \\
$\begin{array}{l}\text { Alveolar length of } \\
\text { upper molar row }\end{array}$ & 16 & 6.3 & $5.8-6.9$ \\
$\begin{array}{l}\text { Length of 1nc1sive } \\
\text { Poramen }\end{array}$ & 16 & 7.5 & $6.6-8.5$ \\
Breadth of rostrum & 14 & 9.3 & $8.2-10.1$ \\
\hline
\end{tabular}


Dasyprocta agut1 ( Linn.)

Dasyprocta rubrata Thomes, Ann. and Mag. Nat. H1st. (7)II, 1898.

Desyprocte agut1 (Linn.), In Allen and Chepmen, Bull. Amer. Mus。 Nat. Hist., V, 1893.

In Guayaguayare the "gut1" is thought by hunters to be next in abundance after the armadillo. One was shot at Guayaguayare on 20 August 1959. One was obtalned from Biche.

Echimys armatus castaneous (Allen and Chapman)

Loncheres guianae Thomas, Trinidad Field Nat. Club I(7), 1892.

Loncheres castaneus Allen and Chapman, Bull. Amer. Mus. Nat. Hist., V, 1893.

Ech1mys armatus Georf.

Proechimys guyannens 18 trinitat is (Allen and Chapman)

Echimys trinitatis Allen and Chapman, Bull. Amer. Mus. Nat. Hist., v, 1893.

The "P1lor1" inhabit the stream banks. One male in breeding cond1tion was shot in Guayaguayare on 29 August 1959. Its measurements were 478-212-56- In 30. One partial skull was found at the edge of the Arlpo River.

Procyon cancrivorus cancrivorus (Cuvier) in Thomss, Trinidad Field Nat. Club I(7), 1892.

Eire berbara trinitat1s (Thomas)

Gelict1s barbare (Linn.) In Allen and Chapmen, Bull. Amer. Mus. Nat. Hist., V, 1893.

Tayra barbara trinitatis Thomas, Ann. and Mag. Nat. Hist. (7) v, 1900. 
Lutre enudris enudris (Cuvier)

Lutre 1nsular1s Thomas, Ann. and Mag. Nat. H1st. (8) I, 1908 Herpestes auropunctatus auropunctatus

Felis pardalis Linn.

Fel1s t1grina Erxl., Allen and Chapman, Bull. Amer. Mus. Nat.

Hist., IX, 1897

Leopardus pardal1s Linn., in Vesey-Fitzgerald, Tropical Agr.

(Tr1n1dad), 13(6), 1936.

Pecari tajacu (IInn.)

D1cotyles tajacu (IInn.), in Allen and Chapman, Bull. Amer. Mus.

Nat. H1st., V, 1893.

Tayassu Pecar1 Fischer

Dicotyles lablatus Cuvier, in Allen and Chapman, Bull. Amer. Mus. Nat. H1st., v, 1893.

Mazama americana trinitat1s (Allen)

Carlacus (Coassus) nemorivagus (Cuvier) in Allen and Chapman, Bull. Amer. Mus. Nat. Hist., V, 1893.

Mazama rupa (Cuvier)

Mazama trinltatis Allen, Bull. Amer. Mus. Nat. Hist., XXXIV, 1915.

Deer are less abundant than Dasyprocta and must be hunted increasingly further away from the population center, Port-of-Spain. They have one or two young, dropping them mainly in the summer. One hunter killed a deer with a well formed fetus in the middle of August. The skull and leg of one specimen was obtalned which was killed during the spring of 1959 in S1paria Forest Reserve. A hunting party with dogs 
killed a lactating doe with a single corpus luteum th the ovary at Tabaquit on 26 June 1959. One buck was shot on 23 August 1959 at Guayaguayare that dressed out at 35 pounds. One deer was seen in the Guayaguayare Forest.

\section{Zoogeographic Affinities}

Trinldad is part of the savannah region of South America as defined by Cabrera (1940). In addition to savannah, however, the region also includes the forested coastal range which is the mountainous extension of the Andes. Trinidad is included in this forested section, and may be considered as the extreme northeastern end of the coestal range. This geographic character is reflected in the present mammal fauns which is composed to a large extent ( 38 percent) of arboreal forms. The savannah faunas which existed on the island in the Ple1stocene is represented by only one relict form, Oryzomys delicatus, In the present fauna, and by one other, Odocolleus gywot1s, of the preColumbian fauna.

Westermann (1953) has stated that "The flora and fauna of Trinldad and Tobago have strong affinities to those of the neighborlng South American continent, but quite a number of species common to the Guianas are absent here. The1r absence is due to natural circumstances and not to extermination by man." When the present land mammals of Trinldad are compared with the mammals of the Guiana Region and Rancho Grande, Venezuela, as reported by Tate $(1939,1947)$, and those of Northern Colomb1a as reported by Hershkovitz (1947, 1948, 1949, 1960), It is found that more than twice as many ( 28 percent) bave affinities 
to the west of Irinidad in Venezuela, Colombia, and the Andes than have affinities to the south in the Gulana region. Those forms with allies to the west are: Cebus alb1frons, Alouatta seniculus, Sciums grenstens1s, Oryzomys delicatus, Rh1p1damys coues 1, Akodon ur1ch1, Heteromys anomalus, and Marmosa carr1, whereas those with allies to the south are Oryzomys concolor, Lutra enudr1s, and Celuromys ph1lander. The remalning forms ( 59 percent) have relatively extens1ve ranges. Th1s assoclation again reflects the geographic ties which Trinidad has had with Venezuela and 1ts recent ecological relationsh1p w1th the forested areas. It also suggests that the Orinoco River constitutes an 1mportant barrier to many widely ranging mammal species. 


\section{DISCUSSION}

Since a large part of this study is besed on enimal bones associated with archeological rema1ns it is appropriate that some of the problems involved in the use of such meterials for zoological interpretation be discussed. It is important to understand the nature of the deposit in which the bones are found, the method of sampling, and the cultural background of the human population represented. The nature of the deposit may be ceremonial where animals are burled as part of a ritual, but more often animal remains are assoclated with kitchen middens. The number of different forms represented in a midden may often be correlated with the economy of the aborigines that made the midden. Usually gathering, hunting, and flshing peoples will depend on a greater varlety of animal foods than agricultural people. Middens are sampled by the archeologist e1ther randomly by a surface collection that may be preliminary to an excavation or by an excavation that systematically samples all parts of the mldden. Each level, the smallest unit of the sample, is of known volume and 0.1 that is found in each level is kept separate for analysis. The zooarcheologist bases his analysis on material sampled in the same manner.

The archeologlst's goal is to reconstruct the life of the aboriginal group he is studying whereas the zoosrcheologist's objective is to reconstruct as far as possible the faunal characterlstic of that period. Such data contribute to the archeologist's interpretation of the relationship of the human population to its natural environment. The 
analysis of particular feunal associations must rest upon a foundation of accurate 1dent1flcat1ons. For this purpose as large series of sikeletons as possible must be obtained and prepared. Usually between 25 percent and 75 percent of the materlal w11l be too fragmentary to 1dent1fy. From the 1dentiflable portion, the relative number of individuals of each species may be determined by calculating the minimum number of 1ndividuals. This must be done to glve equal consideration to each form and not favor those with more bones. With these data a better picture of the former ecology and various changes in the fauna may be revealed. Certain changes in the fauna within one site may become apparent when the materials are analyzed strat1graphically, or between the fauna of the site and the more distant past or present fauna of the same area. Work with the individual specles may reveal new forms, certa1n var1ations of recognized forms, or osteological properties of a species or genus. This material may provide much valuable 1nformation when analyzed with 1ts orlgin in mind.

In this study of samples of past and present mamalian faunas of Trinidad an effort was made to determine the composition of the faunas and to gain some insight 1nto the posalble factors that might have played a role in the formation of the faunas. It 1 s obvious that the fauna w1ll be composed of such forms as have had geograph1c access to the area and whose hab1tats are represented. The foss1l fauna existed at a time when what is now Trinidad was connected to the ma1nland, and savannahs covered most of the area. Foresta grew at h1gher elevations and along streams. The known fossil faun reflects these conditions in 
that it is composed principally of large herbivores of grassland hab1tats. The geological events that resulted in the 1solation of Trinidad as an 1sland also resulted in the rejuvenation of the solls and thereby the spread of forest vegetation. Isolated in this habitat is a recent fauna of entirely different nature. As many as 38 percent of these mammals are arboreal and a great many more are forest dwelling forms.

As would be expected, accompanying the changes in the compos 1tion and 1solation of the faunas are changes in its affinities and percentage of endemism. The fossil faune was composed largely of specles with very wide ranges. There is no endem1sm among the fossil species (with the possible exception of Zygodontomys) since there was no 1solation in the uninterrupted expanse of savannah that spread across Venezuela and Trinidad. The Recent fauna is composed to a large extent of widespread forms that originated princlpally from the west of Trinidad. Evidently the Orinoco River presented a barrier to the movement of certain species from the south to Trinidad. Due to the gradual separation of the 1sland from the mainland, species became 1solated. Th1s is reflected in the extent of endemism now found in Trinidad. Of the 29 land mammals now known from Trin1dad, two Marmosa carr1, and Akodon urich1, are endemic. Twelve endem1c subspec1es are also recognized. Since the colonization of Trinidad by Europeans the 1solation of the 1sland fauna has in one sense broken down and as a result of man's activities the composition of the fauna has been altered. At the present time the forest forms are decressing in numbers as the forest habltat is replaced by agricultural and 1ndustrial areas. With the 
increase in the human population from about 635,843 in 1950 to 825,700 In 1960 a drastic change has been seen in the abundance of game animals. This situation is particularly serious because of three principal factors. The first of these is unemployment resulting from the increase In population. The second is the good market for wild meats that stimulates hunting by the people. Finally the game laws, although reasonably strict, are poorly enforced. Hunters hunt without licenses, shoot protected animals, and animals out of season without hesitation. The clearing of land provides habltats for rodents and particularly Rattus and Mus at the expense of the native forms. A few of the native forms such as Zygodontomys adapted to habitats resulting from cleared land have been able to compete successfully with the introduced forms. However, the persecution of game species would appear inevitably to lead to their extermination if no reservolrs are provided. Perhaps the most practical resolution would be to set aside sanctuarles that could be managed and stringently protected for the replenishment of game in other forested areas. The one area which 18 absolutely protected now is the United States base at Chagaramus where game is said to be plent1ful. As Westermann (1953, p. 12) has said, "The relatively small size of these 1slands, and their rapidly growing population, make the outlook for the preservation of nature rather precarlous, unless large forest and nature reserves can be kept in perpetulty." 
SUMMARY AND CONCLUSIONS

Three semples of mammal bones representing different time periods were studied to see what changes have taken place since the latePle1stocene and to determine the cause of these changes.

The first of these samples was deposited more than 34,000 years ago In a stream edged by gallery forest when Trinidad and Venezuela were broadly connected. The mammal fauna represented was composed of large herbivorous forms as Cuv1eron1us, Glyptodon, Mylodon, and Megatherlum of which all are now ext1nct. In adition to these large mammals one small rodent referable to the genus Zygodontomys was represented. Although a species of Zygodontonys now exists on Trinidad it is not the same spec1es as the fossil form. The foss1l zygodontomys is characterized by 1 t $\mathrm{s}$ very small size. The ecological situation indicated by the fossil mamals is that the area's habltat was grassland and forest.

The second sample was composed of bones excavated at six Indian middens. The mammals represented comprise almost all the larger land mammals native to Trinidad. Those larger than the cricet1d rodent Rh1p1domys coves 1 that were not found are Cyclopes d1dactylus, Cebus alblfrons, and Elra barbara, although the latter has previously been reported from a midden. Specles that do not now occur on the island are Odoco1leus Eymot1s, which probably constitutes a rel1ct; Taysssu pecar1, wh1ch is probably now ext1nct on the 1sland but did appear in the early lists of Trinidad mammals; and Taplms represented by one tooth whlch may have been a trade object. 
The principal difference between sites was not found to be the presence or absence of certain animels, but rather the percentage of comparable and abundant forns. The armadillo was found to be more abundant at sites where the solls are more Priable. At the three sites situated on the south coast in open forest, deer and agout 1 were more abundant than peccary and paca, respectively. At the site in palm forest surrounded by heavy forest agout 1 and paca were almost equally abundant but deer were more abundant than peccary. The two sites located in heavy forest had far more paca and peccary than agout1 and deer, respectively. These differences in the percentage of various forms reveal more subtle differences in the ecology of an area than are revealed by the presence or absence of an incldental form.

The last sample is composed of specimens that were collected by us, and by mamal remains from owl pellets, and includes a compilation of published records. The only unreported form found is a rodent referable to S1gmodon cr. h1rsutus. Th1s record is based on 21 skulls from owl pellets collected originally by F.W. Urich. The Recent fauna is composed to a large extent of forest forms that are allied principally to species from the west of Thinidad or with widespread ranges. These affinfties with the west reflect the past land connection of Trinidad and Venezuela and the barrier of the Orinoco River to the dispersal of certain forms. Today with the removal of forests by man many of the native marmal populations are dwindling. 


\section{LITERATURE CITED}

Allen, J. A. and F. M. Chapman, 1893. On a collect1on of mammals from the Island of Trinldad, w1th descriptions of new species. Bull. Amer. Mus. Nat. H1st., 5(13):203-234.

- 1897. On a second collection of mammals from the Island of Trinldad, with description of new species, and a note on some mammals from the Island of Dominica, W. I. Bull. Amer. Mus. Nat. H1st., $9(2): 13-30$.

Beard, J. S. 1946. The natural vegetat1on of Tr1n1dad. Oxford Forestry Memoirs No. 20, pp. 152.

Bla1r, K. G. 1927. Remains of insects from oll sand in Trinidad. Trans. Entom. Soc. Iondon. 137-142.

Bullbrook, J. A. 1953. On the excavation of a shall mound at Palo Seco, Tr1n1dad, B. W. I. Yale Unfv. Publ. Anthr. No. 50:5-114.

Burt, W. H. 1961. A fauna from an Indian site near Redington, Arizona. J. Mamm. $42(1): 115-116$.

Cabrera, A. 1957. Catalogo de los mamiferos de Amer1ca del Sur. Museo Argentino de Ciencias Naturales "Bernardina Rivadavia." 4(1): $1-307$.

Cabrera, A. and J. Yepes. 1940. Mamiferos Sud: Americanos. Campania Argent1ne de Editiores, Argent1ns, pp. 370.

Cruxent, J. M. and I. Rouse. 1959. An archeological chronology of Venezuela. Vol. I and 2:1-223. Soc1al Sclence Monograph 6 of Pan American Union.

Enllian1, C. 1955. Pleistocene Temperatures. Jour. of Geo., 63(6): $538-557$.

Goodw1n, G. G. and A. M. Greenhall. 1961. A rev1ew of the bats of Trinidad and Tobago. Descriptions, Rab1es infect1on, and ecology. Bull. Amer. Mus. Nat. H1st., 122(3):191-301.

Greenhall, A. M. 1956. Is the Yapok or water opossum found 1n Tr1n1dad? Jour. Trinldad Field Naturalist's Club, p. 27.

Gyldenstolpe, N. 1932. A manual of Neotropical Sigmodont rodents. Kungl. Svenska Vetenskapsakadem1ens Handl1ngar. I1(3):1-164. 
Hershkov1tz, P. 1947. Mamals of Northern Colombla preliminary report No. 1: squirrels (Sc1uridae). Proc. U. S. Nat. Mus. 97(3208) 1-46.

- 1948. Mammals of Northern Colomb1a preliminary report No. 2: Spiny rats (Echimyidae), with supplemental notes on related forms. Proc. U. S. Nat. Mus. 97(3214):125-140.

- 1948. Mammals of Northern Colombia preliminary report No. 3: water rats (genus lectomys), with supplemental notes on related forms. Proc. U. S. Nat. Mus. 98(3221):49-56.

- 1949. Mammals of Northern Colombia preliminary report No. 4: monkeys (Primates), with taxonomic revision of some forms. Proc. U. S. Nat. Mus. $98(3232): 323-427$.

- 1955. South American marsh rats genus Holochilus with a sumary of s1gmodont rodents. Fieldiana: Zool. 37:639-673.

- 1960. Mammals of Northern Colomb1a preliminary report No. 8: Arboreal rice rats, a systematic revision of the subgenus Decamys, genus Oryzomys. Proc. U. S. Nat. Mus. 110(3420):513-568.

Koldew1jn, B. W. 1958. Sediments of the Paria-Trinidad shelf. Mouton and Co.' 'S-Gravenhage, the Hague, pp. 109.

Nota, D. J. G. 1958. Sediments of the western Gulana shelf. Mededelingen van de Landbouwhogeschool Te Wageningen. Nederland, pp. 98.

Osborn, H. F。 1936. Proboscidea. A monograph of the discovery, evolution, migration and extinction of the mastodonts and elephants of the world. Amer. Mus. Nat. H1st., 1:1-802.

Rouse, I. 1953. Append1x B: Indian sites in Trin1dad, in Bullbrook: Excavation at Palo Seco, Trinidad. Yale Unlv. Publ. Anthr. No. $50: 94-111$.

Schaub, S. 1935. Säugetierfunde aus Venezuela and Trinidad. Abh. Schwe1zerischen Palaeontologischen Gesellschaft. 55:1-21.

Seton, E. T. 1929. Lives of game an1mals. Vol, 3, part 2. Doubleday, Doran and Co., Inc., New York, pp. 780.

Simpson, G. G. and C. de Paula Couto, 1957. The mastodonts of Braz1l, Bul1. Amer. Mus. Nat. H1st. $112(2): 125-190$.

Tute, G. H. H. 1939. The mammals of the Guians region. Bull. Amer. Mus. Nat. Hist. 76(5):151-229. 
- 1947. A list of the mamals collected at Rancho Grande, In a montane cloud forest of northern Venezuela. Zoologica $32(7): 65-66$.

Taylor, W. W. (ed.) 1957. The identification of non-artifactual archaeological materials. Nat. Acad. Sc1.-Nat. Res. Council. Publ. 565:1-64.

Thomas, 0. 1893. A preliminary 11st of the mammals of Trinidad. Jour. Trinidad Field Naturalists' Club 1(7):158-169.

Verteu1l, L. A. A. de. 1384. Trinidad: its geography, natural resources, administration, present condition, and prospects. Cassel and Co., Ltả. London, pp. 484.

Vesey-Fitzgerald, D. 1936. Trinidad manmals. Tropical Agriculture $13(6): 161-165$.

Westermann, J. H. 1953. Nature preservation in the Caribbean. Publ. of the Found. for scientific research in Surinam and the Netherlands Ant1lles. No. 9, pp. 106. 


\section{BIOGRAPHICAL SKETCH}

Anne Ellzabeth Schwarz was born In Cambridge, Massachusetts, March 5, 1932. She attended the W1asor School in Boston, Massachusetts, and was graduated in 1951. In 1955 she recelved her Bachelor of Arts degree from Mount Holyoke College in South Hadley, Massachusetts, and 1n 1957 she recelved her Master of Sclence degree from the University of Florida.

During her graduate studies she has held graduate assistantships In the Department of Biology and Floride State Museum. In the summer of 1959 she was awarded a National Sclence Foundation Sumer Fellowship for Graduate Teaching Ass1stants. She is presently employed as a research associate of the Florida State Museum on a zooarcheological project supported by the National Sclence Foundation, Grant 17948.

She 18 a member of Sigma $X i$ and Phi Sigma socleties and the American Soclety of Mammalogists.

On Apr11 18, 1957, she was marrled to James E. W1ng, Jr. and has one ch1ld, Mary El1zabeth, born September 12, 1961. 
This dissertation wos prepared under the direction of the chalrman of the candidate's supervisory comittee and has been approved by $a \geq 1$ members of the committee. It was submitted to the dean of the College of Arts and Sclences and to the Graduate Counc1l and was approved as partial fulf1llment of the requirements for the degree of Doctor of Philosophy.

February 3, 1962

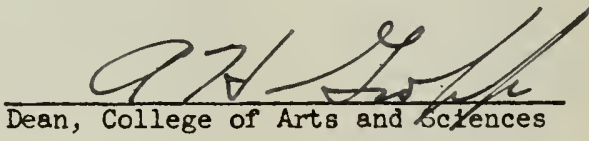

Dean, Graduate School

SUPERVISORY COMMITTEE:
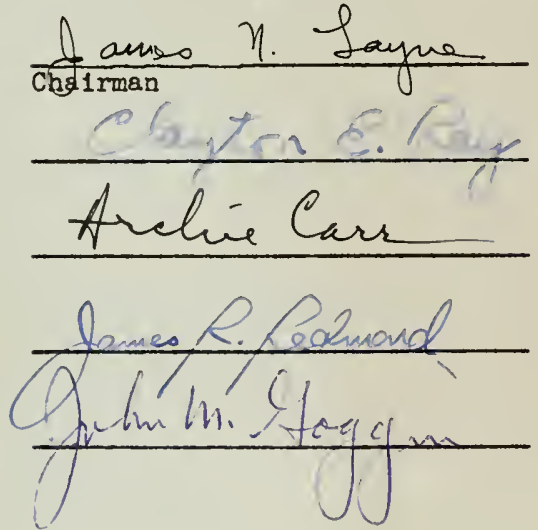